Review

\title{
Potential Protective Role Exerted by Secoiridoids from Olea europaea L. in Cancer, Cardiovascular, Neurodegenerative, Aging-Related, and Immunoinflammatory Diseases
}

\author{
María Luisa Castejón (D), Tatiana Montoya, Catalina Alarcón-de-la-Lastra and \\ Marina Sánchez-Hidalgo *(D) \\ Department of Pharmacology, School of Pharmacy, University of Seville, 41012 Sevilla, Spain; \\ mcastejon1@us.es (M.L.C.); tmontoya@us.es (T.M.); calarcon@us.es (C.A.-d.-l.-L.) \\ * Correspondence: hidalgosanz@us.es; Tel.: +34954557469; Fax: +34954556074
}

Received: 30 December 2019; Accepted: 7 February 2020; Published: 10 February 2020

\begin{abstract}
Iridoids, which have beneficial health properties, include a wide group of cyclopentane $[c]$ pyran monoterpenoids present in plants and insects. The cleavage of the cyclopentane ring leads to secoiridoids. Mainly, secoiridoids have shown a variety of pharmacological effects including anti-diabetic, antioxidant, anti-inflammatory, immunosuppressive, neuroprotective, anti-cancer, and anti-obesity, which increase the interest of studying these types of bioactive compounds in depth. Secoiridoids are thoroughly distributed in several families of plants such as Oleaceae, Valerianaceae, Gentianaceae and Pedialaceae, among others. Specifically, Olea europaea L. (Oleaceae) is rich in oleuropein $(\mathrm{OL})$, dimethyl-OL, and ligstroside secoiridoids, and their hydrolysis derivatives are mostly OL-aglycone, oleocanthal (OLE), oleacein (OLA), elenolate, oleoside-11-methyl ester, elenoic acid, hydroxytyrosol (HTy), and tyrosol (Ty). These compounds have proved their efficacy in the management of diabetes, cardiovascular and neurodegenerative disorders, cancer, and viral and microbial infections. Particularly, the antioxidant, anti-inflammatory, and immunomodulatory properties of secoiridoids from the olive tree (Olea europaea L. (Oleaceae)) have been suggested as a potential application in a large number of inflammatory and reactive oxygen species (ROS)-mediated diseases. Thus, the purpose of this review is to summarize recent advances in the protective role of secoiridoids derived from the olive tree (preclinical studies and clinical trials) in diseases with an important pathogenic contribution of oxidative and peroxidative stress and damage, focusing on their plausible mechanisms of the action involved.
\end{abstract}

Keywords: immunomodulation; inflammation; olive tree; oxidative stress; secoirioids

\section{Introduction}

Iridoids, which have beneficial health properties, include a wide group of cyclopentane $[c]$ pyran monoterpenoids present in plants and insects. The name iridoid derived from Iridomyrmex, a genus of fornices from which iridomirmecin and iridodial compounds were isolated. These products have been considered as defensive compounds. In fact, the biosynthesis of these derivatives of monoterpenes takes place in the different organisms by similar pathways; defense is its main role, and in the case of insects, they are used as sex pheromones [1].

Iridoids were first isolated in the latter part of the 19th century, but Halpern and Schmid proposed the basic skeleton of the iridoids in their investigation of the structure of plumieride in 1958 [2]. Particularly, they are secondary metabolites of terrestrial and marine flora and fauna, being found in a large number of plants families, usually as glycosides. For this reason, some of them are 
chemotaxonomically useful as markers of genus in various plant families. Besides, they exhibit a wide range of bioactivities including anti-inflammatory, antibacterial, anti-carcinogenic, and antiviral activities [3]. In fact, they are used as bitter tonics, sedatives, antipyretics, cough drugs, remedies for skin disorders, and as hypotensive agents. In addition, they are useful as an antidote in mushroom intoxications by Amanita type.

The cleavage of the cyclopentane ring of iridoids leads to secoiridoids. Mainly, secoiridoids have shown a large variety of pharmacological properties including anti-diabetic, anti-inflammatory, immunosuppressive, neuroprotective, anti-cancer, and anti-obesity. This fact encouraged us to study the bioactivities of these phytochemicals in depth and update the latest preclinical and clinical data on its bioactivity and potential therapeutic uses.

\subsection{Structure and Classification}

Several classifications have been developed over the years, given the variety and complexity of iridoids and secoiridoids $[4,5]$.

From 1980 to date, bibliographic data has used the classification proposed by El-Naggar and Beal [2], who categorize these compounds according to the number of carbons included in their structure:

- Group 1: $\mathrm{C}_{8}$ iridoids (di-nor-iridoids)

- Group 2: $\mathrm{C}_{9}$ iridoids (nor-iridoids)

- Group 3: $\mathrm{C}_{10}$ iridoids, which occur mainly as glycosides

- Group 4: Aglycones and some iridoids included in the other three groups lacking a sugar residue in their structure

- Group 5: Iridoids derivatives. This group comprises compounds derived from the opening of the pyran ring

- Group 6: Included bis-iridoids as a result of condensation of two monomers, (a) directly as in iridolinalin $\mathrm{A}$, or (b) through a sugar residue as in globuloside A.

At the same time, there are other classifications of secoiridoids according to the presence of these compounds in certain families, including the Oleaceae family. In fact, a total of 232 secoiridoids (aglycones, glycosides, derivatives, and dimers) have been isolated from nine genus of the family Oleaceae. These genera include Fontanesia, Fraxinus, Jasminum, Ligustrum, Olea, Osmanthus, Phillyrea, Picconia, and Syringa, and these secoiridoids were classified into other five groups [6]:

- Simple secoiridoids: Generally, for the simple secoiridoids, positions $C_{7}$ and $C_{11}$ have either a free carboxylic acid group or a methyl ethyl ester derivative of the acid. The configurations of the positions $\mathrm{C}_{1}$ and $\mathrm{C}_{5}$ are $S$.

- Conjugated secoiridoids: This group of compounds is the most numerous secoiridoids isolated from the Oleaceae family. The name of the class derives from the type of compound that is linked or conjugated to the secoiridoid nucleus. Based on this, this class is further categorized into seven subgroups: aromatic-conjugated, sugar-conjugated, terpene-conjugated, cyclopentane-conjugated, coumarin-conjugated, lignans-conjugated, and other secoiridoids. Normally, the conjugations occur in $C_{7}$ due to this position, which is is usually oxidized to a carboxylic acid and esterified with diverse groups.

- 10-Oxyderivative of oleoside secoiridoids: This group contains the oleoside nucleus with distinct structural differences. The $\mathrm{C}_{8}$ and $\mathrm{C}_{9}$ positions exist as double bonds, with a hydroxy group at the $\mathrm{C}_{8}$ position or an ester formed by an oxygen atom with different groups. A total of 40 10-Oxyderivative of oleoside secoiridoids have been isolated from the Oleaceae family.

- Z-Secoiridoids: This class of secoiridoids is characterized by the presence of double-bond geometry at the $\mathrm{C}_{8}$ in Z-configuration; however, only five compounds have been isolated from the Oleaceae family. 
- Secologanosides and oxidized secologanoside secoiridoids: Compounds of this class are based on the secologanoside nucleus. They are differentiated by the positions on the $\mathrm{C}-\mathrm{C}$ double bond between $\mathrm{C}_{8}$ and $\mathrm{C}_{10}$ and $\mathrm{C}_{10}$ oxidation level.

\subsection{Main Naturally Occurring Iridoids and Secoiridoids Present in Olea europaea $L$}

Iridoids and secoriridoids are thoroughly distributed in the plants of class Magnoliopside, concretely belonging to the following families: Scropulariaceae, Verbenaceae, Lamiaceae, Apocynaceae, Loganiaceae, Bignoniaceae, Plantaginaceae, Rubiaceae, Pedaliaceae, Cornaceae, Acantheceae, Loasaceae, Lentibulariaceae, Gentianaceae, Oleaceae, Nyctanthaceae, Caprifoliaceae, Dispsacaceae, and Valerianaceae.

For instance, Valeriana officinalis L. (Valerianaceae), Harpagophytum procumbens L. (Pedaliaceae), Genciana lutea L. (Gentianaceae), Fraxinus excelsior L. (Oleaceae) and Olea europaea L. (Oleaceae) are the most representative medicinal plants commonly used in medicine, due to their iridod/secoiridoid content [3]. Particularly, Olea europaea L. (Oleaceae) is a small evergreen tree with firm branches and a grayish bark. The leaves are lanceolate, opposite, short-petioled, mucronate, green above and hoary on the underside. On the other hand, the flowers are small, short, erect racemes, axillary, very much shorter than the leaves, and the fruit is a small smooth, purple, or green drup, with a nauseous, bitter flesh, enclosing a sharp-pointed stone [7].

Olea europaea L. preparations have been traditional used in folk medicine in the European Mediterranean area, Arabia peninsula, India and other tropical and subtropical regions, as a diuretic, emollient, hypotensive, and for urinary and bladder infections [8]. Most of the plant parts of Olea europaea L. are used in the traditional system of medicine around the world. Oil is taken with lemon juice to treat gall stones [9]. Leaves are taken orally for stomach and intestinal diseases and used as mouth cleanser [10], and the decoction of dried leaves is taken orally for diabetes [11]. An extract of the fresh leaves is taken orally to treat hypertension and to induce diuresis [12], whereas an infusion of the fresh leaves is taken orally as an alternative treatment for inflammatory diseases [13]. Similarly, essential oil extracted from the fruit is also used to treat rheumatism, promote blood circulation [14], and as a laxative [15].

The main biophenol secoiridoids found in the olive tree include: oleuropein (OL), dimethyl-OL, ligstroside, and their hydrolysis derivatives such as OL-aglycone, oleocanthal (OLE), oleacein (OLA), elenolate, oleoside-11-methyl ester, elenoic acid, hydroxytyrosol (HTy), and tyrosol (Ty) (Figure 1).

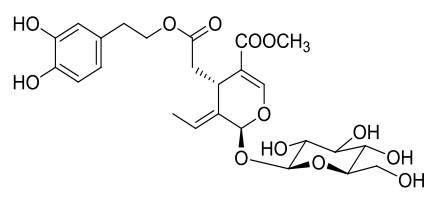

$\mathrm{OL}$

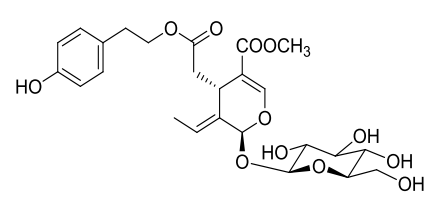

Ligstroside

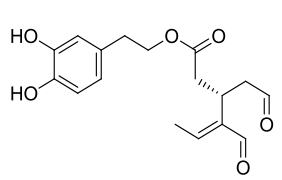

OLE

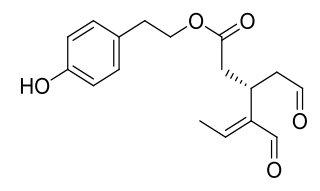

OLA

Figure 1. Chemical structures of secoiridoids most abundant in olive trees. OL: oleuropein, OLA: oleacein, OLE: oleocanthal. 


\subsection{Biosynthesis and Biotransformation of Secoiridoids in Olive Tree}

The amount and distribution of secoiridoids present in olive tissues depend on various environmental factors such as the ripening cycle, geographical origin, and cultivation practices, among others. Besides, the content of phenolic glycosides as patterns and the activity of endogenous enzymes can play a role in the quantitative composition of secoiridoids in the olive tree [16].

The fact that secoiridoids are mostly present in early stages is due to the enzymatic and chemistry reactions that take place in the maturation time. In this sense, three different states in fruit maturation have been described: growth phase, green maturation phase, and black maturation phase, which is characterized by the presence of anthocyans.

OL is mainly abundant in early stages, although its levels decrease during the maturation process. In fact, OL decreases quickly in black crops and is not present in some varieties of Oleaceae.

The main precursor of OL and ligstroside is oleoside 11-methyl ester (elenolic acid glucoside). Firstly, geraniol synthase (GES) catalyzes the transformation of genaryl diphosphate to geraniol, which is converted to 10 -hydroxygeraniol by the geraniol 10-hydroxylase enzyme. The iridioids in Oleaceae must be formed from this point with 10-hydroxygeraniol as the starting compound via irididal and iridotrial up to deoxyloganic acid, which is the precursor of loganin and loganic acid, as well as secologanin and secologanic acid [17]. From this point, up to five routes have been proposed to explain the origin of all iridoids found in this family. However, it is known that most of the secoiridoids present in Olea europaea L. are derived from deoxyloganic acid as a common intermediate $[17,18]$. Following this line, nicotinamide adenine dinucleotide deshydrogenase (NADH) acts on 10-hydroxygeraniol to form deoxyloganic acid aglucone. The transfer of glucosyl groups to deoxyloganic acid aglucone (precursor of monoterpene indolic alcaloids and OL) is catalyzed by glucosyltransferase (GT). Deoxyloganic acid experiments a 7- $\alpha$-hydroxylation of the cyclopentane ring and forms 7-epiloganic acid, which quickly goes to 7-ketologanic acid through hydroxyl group oxidation. Loganic acid methyltransferase catalyzes 7-ketologanin syntheses. In this point, secologanin synthase (SLS) oxides a ketonic group to form 11-methyl oleoside, which is immediately glucosylated by GT. Finally, 7- $\beta$-1-D-glucopyranosyl-11-methyl oleoside is esterified with Ty to produce ligstroside, and then OL is formed [17,19] (Figure 2).

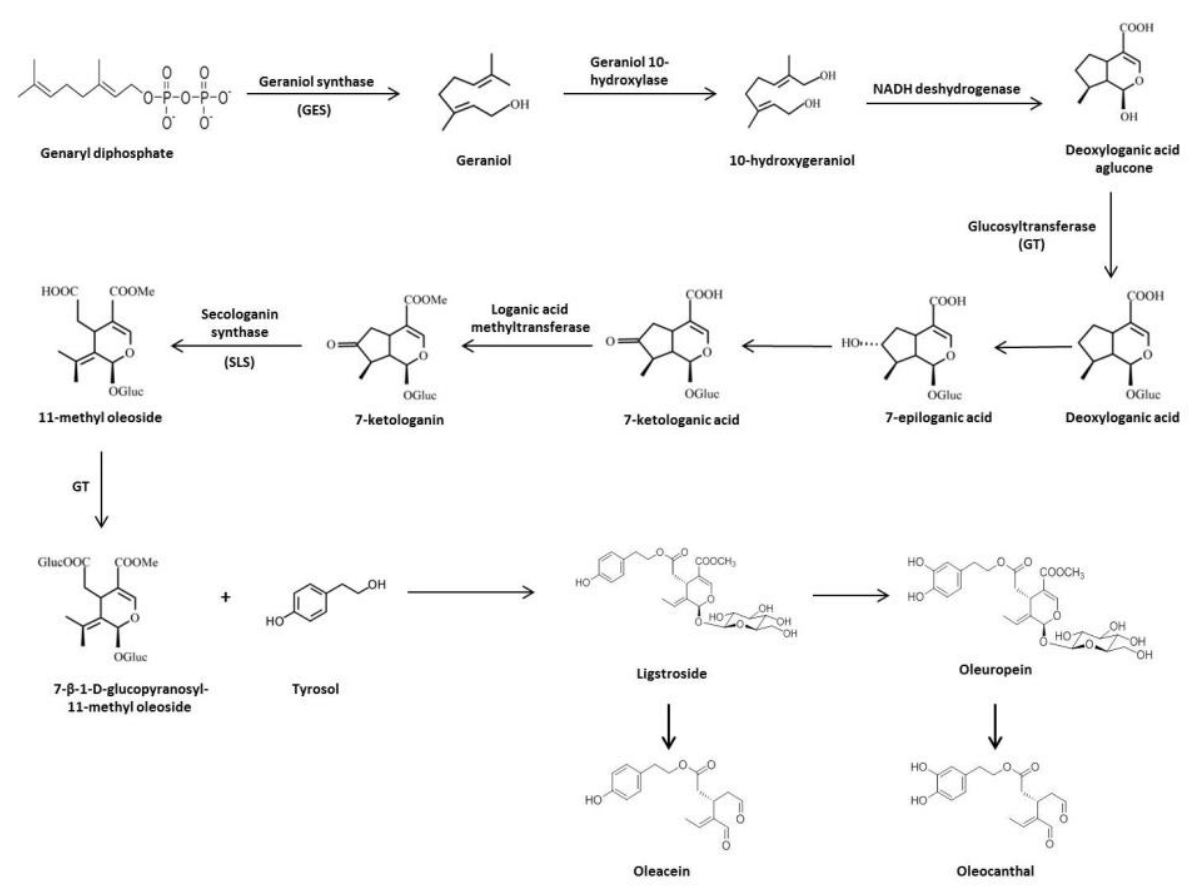

Figure 2. Biosynthesis and biotransformation of secoiridoids in Olea europaea L. 
Secoiridoids are distributed throughout the tissues of the olive tree, but their nature and concentration change among different parts of the plant. Thus, biosynthetic or mechanicals transformation during production are decisive to quantify alterations of the bioactive small molecules [18]. Particularly, OL is the major secoiridoid constituent of unripe drupes (peel, pulp, and seed). The amount of OL decreases along fruit maturation, as commented above, whereas its aglycon form increases its levels. OL-aglycone is formed by the cleavage of the glycosidic bond mediated by $\beta$-glucosidase activity. Ligstroside has been described as a common phenolic component in different olive tissues (leaf, fruit pulp, and stone) and olive oil, but it has been rarely found in olive seeds [20].

In the course of maturation, $\mathrm{OL}$ and ligstroside are considered pattern components. Both of them are present in the olive fruit, but they are almost non-existent in olive oil (85-95\% reduction) [21,22]. $\beta$-glucosidase acts by decreasing OL and ligstroside levels, aglycon forms from OL, and ligstroside can be detected as isomers due to the keto-enolic tautomeric equilibrium of the elenolic acid moiety [23,24].

Other dialdehydics structurally related to these secoiridoid precursors are OLA and OLE. Different authors have reported that both OLA and OLE levels increase during ripening due to OL and ligstroside degradation, respectively [25]. Thus, they concluded that OL and ligstroside are natural precursors of OLA and OLE as breakdown products resulting from enzymatic activity during the extraction and maturation processes [26-29].

OL and ligstroside have been detected in olive leaves. In turn, OLA and OLE levels are augmented in mature fruits, such as OL and ligstroside aglycons. Moreover, OLA and OL-aglycone are more plentiful in olive oil [16].

\subsection{Functional and Physiological Chemistry of the Main Secoiridoids of Potential Medical Interest}

ROS have a remarkable role in the development of oxidative stress and also in the pathology of numerous diseases. For example, oxidative stress is one of the major cellular features in the onset of many pathological conditions such as Alzheimer's and Parkinson disease, renal injury, diabetes, cardiovascular diseases, cancer and aging; it occurs when excessive ROS accumulation produced during the normal cell metabolic processes is unbalanced by the antioxidant defence system [30], and it may induce the oxidative modification of cellular macromolecules including lipids, proteins, and nucleic acids [31].

Previous epidemiological studies show that the Mediterranean diet is associated with a low incidence of cardiovascular disease or cancer. This may reflect the nutritional effects of the bioactive compounds contained in its major source of fatty acids, i.e., extra-virgin olive oil (EVOO), which is rich in phenolic compounds [32,33]. The phenolic compounds contained in EVOO include HTy, Ty, and their secoiridoids precursors such as OL, OLE, or OLA, among others.

A large number of studies highlighted the antioxidant properties of these compounds including their abilities to promote the activity of ROS-detoxifying enzymes, such as superoxide dismutase (SOD), catalase (CAT), glutathione reductase (GSR) and glutathione S-transferase (GST), to compete with coenzyme $\mathrm{Q}$ as an electron carrier in the mitochondrial electron transport chain, which is a site of ROS generation, to act as free-radical-scavenging antioxidants and to inhibit lipid peroxidation [31,34]. In particular, it was shown that dietary OL and OLE treatments were associated with reductions in the production of superoxide anion radical in human monocytes from healthy donors [35]. Similarly, OL administration significantly increased the SOD and glutathione peroxidase (GPx) activity levels in the obstructed kidneys from rats with unilateral ureteral obstruction induced-kidney injury [36]. These results are in accordance with other reports showing that OL was able to increase the amount of enzymes such as GPx and SOD in gentamicin-induced renal toxicity and cisplatin-induced renal injury models $[37,38]$. The phenolic compounds present in Olea europaea L. activated enzymatic and non-enzymatic antioxidant defense mechanisms, particularly preventing cell membrane damage by high-dose UV-B rays [39]. 
Vitamin E ( $\alpha$-tocopherol) is an essential micronutrient in the diet of all mammals, and it is a potent antioxidant in biological systems. This compound is the main chain-breaking antioxidant that prevents the propagation of free radicals reactions, and consequently prevents the tissue damage. In this sense, it has been reported that supplementing the diet with OL for 21 days maintained higher levels of $\alpha$-tocopherol in liver of female Wistar rats [40].

The most important antioxidant activity of the olive tree phenolic compounds is related to the free-scavenging ability because they inhibit the propagation chain during the oxidation process through the donation of radical hydrogen to alkylproxyl radicals and the formation of stable derivatives during this reaction. These compounds also act as metal chelators, preventing the generation of high concentrations of hydroxyl radicals [41]. This capacity may be reduced by the presence of the $-\mathrm{COOOH}_{3}$ fragment in several secoirioids structures, because it seems to cause a decrease in the antioxidant activity which is related to the inability of this group to act as an H-donor [42]. In fact, OL-aglycone presents better radical-scavenging capacity than single hydroxyl substitutions, such as Ty, and also protects low-density lipoprotein (LDL) from oxidation [43].

The relationship between oxidative stress and inflammation has been established by many authors. The pathogenic role of mixed advanced glycoxidation products (AGE) and advanced lipid peroxidation products (ALE) generated in the course of oxidative stress and their adducts with cell biomolecules, such as proteins and nucleic acids, in a number of chronic inflammatory and autoimmune diseases is well documented [44].

On the other hand, in the past years, the leaves of Olea europaea L. have been considered as an important source of antioxidant compounds. In this case, OL is the most predominant and active phenolic compound (60-90 mg/g dried olive leaves), and it is usually considered as an antioxidant reference in comparison with other secoirioids [45,46]. OL contains active components in its molecule with conferred a potential antioxidant activity. It has been suggested that these properties are related to the H-atom donation from the phenolic groups present in OL. For example, OL administration showed a protective effect against ROS production in endothelial cells since OL showed good cytocompatibility and antioxidant activity, which revealed effectiveness in controlling the oxidative stress upon exposure to $\mathrm{H}_{2} \mathrm{O}_{2}$ [47]. In addition, $\mathrm{OL}$ presented slightly weaker radical scavenging activity than HTy by 2,7-dichlorodihydrofluorescein diacetate (DCFH-DA) and ABTS methods [48] and the ability to inhibit LDL oxidation by scavenging free radicals [49].

Although the studies about the antioxidant activity of OLE are limited, it has been demonstrated that OLE could inhibit nicotinamide adenine dinucleotide phosphate oxidase (NOX) in isolated human monocytes, and also OLE was able to reduce intracellular ROS levels in SH-SY5Y cells. Recently, Montoya et al. have also showed that OLE produced a potent reduction of intracellular ROS and nitrites production in LPS-induced murine peritoneal macrophages [50].

OLA is one of the major phenolic compounds present in the olive tree, but its antioxidant profile is more unknown in comparison with other secoirioids, such as OL. However, OLA has demonstrated to be a potent scavenger of $\mathrm{HOCl}$ and myeloperoxidase release and exerts a stronger inhibitory capacity of neutrophil's oxidative in comparison to OL [32].

\subsection{Pharmacokinetics of Secoiridoids from the Olive Tree}

Numerous investigations have revelead the beneficial effects of olive leaves and olive oil for the treatment of many diseases. The possibility that their constituents may achieve any biological effects depends on the chance of reaching molecular targets in a specific tissue or organ at a sufficient dose, which is dependent on their metabolism and bioavailability [51].

The mechanism of intestinal absorption of olive oil phenols is unclear, as it does not appear to be strictly dependent on the polarity of these compounds. For example, OL, which is apolar, is able to diffuse through the lipid bilayer of the epithelial cell membrane. However, also, the more polar HTy appears to be absorbed via a passive bidirectional diffusion mechanism [52,53]. 
To date, reports regarding the bioavailability of the phenolic compounds present in olive oil are extended, whereas bioavailability studies concerning secoiridoids derivatives such as OL, OLE, and OLA have been scarcely studied. Thus, data on the bioavailability of these secoiridoids compounds in human and even animals would be of great interest in order to establish their potential health benefits.

Generally, secoiridoids from Olea Europaea L. are mainly present in glycosylated forms (OL and ligstroside). For this reason, after oral administration, enzyme from saliva starts a hydrolysis process continued in the stomach by digestive enzymes and $\beta$-glycosidases. The unmodified forms could be absorbed to the small intestine or colon, where they are hydrolyzed, finally [54]. The result of this hydrolytic process is the formation of derived aglycon forms. At the same time, the aglycons that were formed could be absorbed in the small intestine or colon. The chemical structure and vehicle of administration are decisive for the rate and extension of gastrointestinal absorption. Structural modifications occur via conjugation in small intestinal epithelial cells or in liver, after transport through the portal system. Metabolites reach the general blood circle, from which they are excreted in the urine [55].

Related to OL, some authors suggest that it could be absorbed in the small intestine or colon. In this sense, Kendall et al. reported that OL diffuses in the stomach and remained stable and intact at the gastric level during digestion being absorbed in the small intestine in healthy young adults [56]. Similarly, several studies have established that OL is stable at the gastric level during digestion, since the bioavailability of its main metabolite HTy is higher [57]. On the contrary, Corona et al. determined that OL was absorbed in the colon and degraded by gut microbiota in rat intestinal segment that produces HTy, which expresses biological activity [58]. Further studies developed in rats confirmed that OL and HTy were present in plasma, feces, and urine as such, and also conjugated as glucuronide after oral OL administration [59-61]. Besides, there are several studies that focus on the study of the colonic pathway of phenolic compounds present in the olive tree. For example, Mosele et al. have demonstrated that OL hydrolysis formed OL-aglycone, elenoic acid, HTy and HTy-Ac in vitro, which is probably a consequence of the hydrolytic transformation making all of them less resistant to the gastric acidic hydrolysis in comparison to $\mathrm{OL}$ and more sensitive to temperature, $\mathrm{pH}$, and enzyme activity. However, OL administration detected other related metabolites such as homovanillic acid in rats [62]. These divergences could be explained taking into account the differences found between both murine and human models.

Surprisingly, it has been postulated that plasma peak at 1 hour (h) after OL administration for humans or $2 \mathrm{~h}$ for a murine model, although OL could be detected after 10 minutes (min) [56,63]. In addition, glucuronides and OL sulfate derivatives could be detected in plasma (at $23 \mathrm{~min}$ ) or in the urine (at $8 \mathrm{~h}$ ) after ingestion. Particularly, De Bock and colleagues described a heterogeneous effect in OL leaf extract bioavailability and metabolism that was dependent on a number of factors, including preparation (capsule/liquid) and gender [63]. In fact, they found that compared to capsules, OL leaf extract in a liquid formulation led to a greater OL peak levels and area under the curve (AUC) in plasma and described that males may be more efficient at conjugating OL.

The production of metabolites during the metabolism process of these compounds could be interesting given that these new compounds may also exert beneficial effects on the organism. The metabolism of secoiridoids can be carried out by phase I (hydrogeneration, hydroxylation, hydratation, etc) or phase II reactions (glucuronidation, methylation, sulfation, etc.). A perfused rat intestinal model determined that the major small intestine metabolites from OL-aglycone were glucoronide conjugates, so they are not absorbed in parental form [64]. OL-aglycone and ligstroside aglycone present a $55 \%-66 \%$ rate of absorption in humans. The aglycon forms were excreted in urine as HTy or Ty [65]. Particularly, during gastric digestion, OL, OL-aglycone, and other phenolic compounds are transformed into HTy, which is throughout transformed into its phase II metabolites (glucuronide and sulfate conjugates) and into HTy-Ac by effect of the acetyl-CoA enzyme [66]. OL and ligstroside formed sulfate and glucuronide conjugates during absoption after undergoing extensive first-pass intestinal/hepatic metabolism, whereas concentrations of their free forms are not detected in the body 
fluids. These compounds were absorbed quickly after oral administration and then were metabolized and excreted in the urine mainly as glucuronide [67]. The catabolism of OL could produce phenylacetic and phenylpropionic catabolites which then could be absorbed and subsequently transforme into phase II metabolites. Thus, compounds such as ligstroside or OL could be absorbed as such or reabsorbed in the form of their respective glucuronide conjugates [58,68].

The bioavilability of OLE is still very limited. Ligstroside aglycone and OLE are hydrolyzed in the acidic gastric environment in the stomach, leaving free Ty after $30 \mathrm{~min}$. OLE is absorbed in the small intestine mediated by passive diffusion through the membrane, which is favorable given an adequate coefficient of partition ( $\log \mathrm{P}=1.02$ ) and stability in acid gastric [69]. In fact, Romero et al. verified that OLE was stable in gastric acid conditions at $37^{\circ} \mathrm{C}$ for $4 \mathrm{~h}$ [70]. Although it has been postulated that OLE is mainly metabolized by Phase I (hydrogenation, hydroxylation, and hydration) [71,72], some hydrogenated metabolites pass to Phase II of metabolism as glucoronidated forms [54], whereas methylated or sulfate forms of OLE have not been detected in any study in humans to date [71,72]. The report published by García-Villalba et al. revealed that OLE and several secoiridoids metabolites were excreted in human urine between 2 and $6 \mathrm{~h}$ after olive oil ingestion [72].

On the other hand, OLA may be absorbed in the small intestine by passive diffusion through the membrane due to its favorable partition coafficient. OLA was found to be stable at gastric acid remaing unalterated after $4 \mathrm{~h}$ of incubation [73]. After the consumption of olive oil, De las hazas et al. [66] described that OLA was hydrolyzed into HTy and elenoic acid in the digestive system and further metabolized by the enzymatic systems.

In conclusion, there are a lot of plants that have been used as medicines since time immemorial; specificallys, Olea europaea L. is a species rich in compounds that have proven their efficacy in the management of several complex diseases including cardiovascular disorders, diabetes, and viral and microbial infections, but additional works are still really necessary to explore the evidences for other traditional uses of this plant. Particularly, the antioxidant, anti-inflammatory, and immunomodulatory properties of secoiridoids from the olive tree (leaves and fruits) have been suggested as a potential application in several oxidative stress-mediated diseases including cancer, cardiovascular disorders, neurodegeneration, the aging process and immunoinflammatory diseases. Thus, the purpose of this review is summarize recent advances in the protective role of these secoiridoids derived from olive tree (preclinical and clinical studies) in these pathologies derived from oxidative stress and focusing on their plausible mechanisms of action involved.

\section{Protective Role of the Olive Tree Secoiridois in Diseases with an Important Pathogenic Contribution of Oxidative and Peroxidative Damage}

\subsection{Olive Tree Secoiridoids and Cancer}

Cancer is a complex chronic degenerative disease characterized by a multistep process in which normal cells turn into malignant cells, acquiring several properties such as abnormal proliferation and reduced apoptosis.

The main factors that cause the majority of cancer cases are tobacco and dietary habits. In fact, there is an estimation that around 30\% of all cancers may be avoidable by changing food intake [74,75]. Therefore, the identification and characterization of foods and their components, which could prevent the incidence and development of cancer, is an important objective for modern nutritional research $[74,76]$. In this sense, it is important to take into account that populations who are living near to the Mediterranean area have a lower incidence of cancer compared to other regions. This fact is probably due to the consumption of the diet known as the Mediterranean diet [77]. Besides, it is well-known that the pathophysiology of common diseases states such as cancer, cardiovascular disease, arthritis, and neurodegenerative diseases, among others, are associated with chronic inflammation [78].

There are a large numbers of studies that support the chemopreventive role of natural compounds derived from EVOO and the olive tree such as OL, OLE, OLA, or ligstroside against different cancers 
and inflammation process. Particularly, the role of secoiridoids derived from Olea europaea L. has been investigated in different types of cancerous processes (Tables 1 and 2).

Table 1. Most recent in vitro studies that corroborate the important role of secoiridoids from the olive tree in the control and progression of different types of cancer.

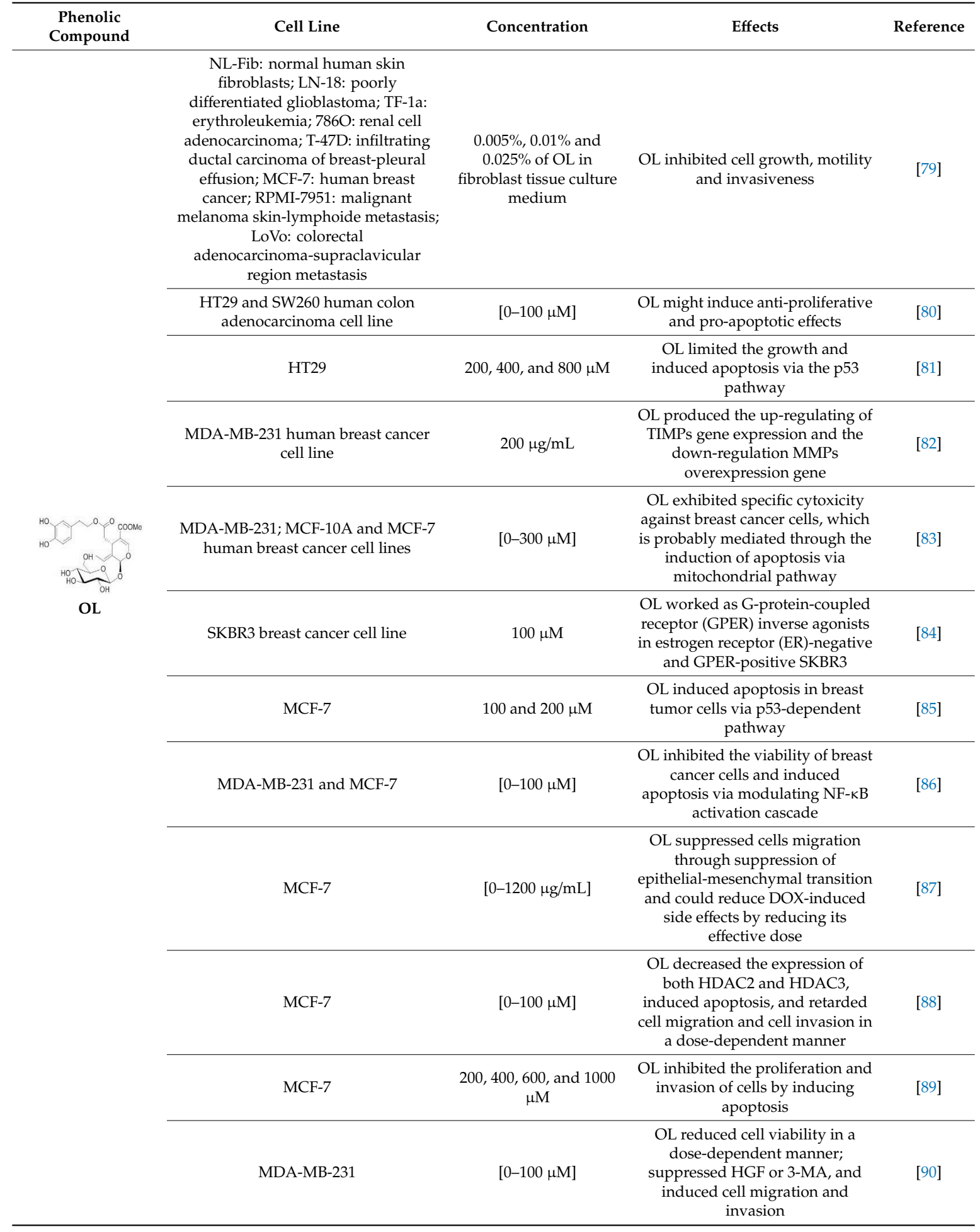


Table 1. Cont.

\begin{tabular}{|c|c|c|c|c|}
\hline $\begin{array}{l}\text { Phenolic } \\
\text { Compound }\end{array}$ & Cell Line & Concentration & Effects & Reference \\
\hline & MCF-7 & {$[0-250 \mu \mathrm{M}]$} & $\begin{array}{l}\text { OL inhibited protein tyrosine } \\
\text { phosphatase 1B (PTB1B) }\end{array}$ & [91] \\
\hline & $\begin{array}{l}\text { HepG2 and Huh7 human HCC cell } \\
\text { lines }\end{array}$ & {$[0-100 \mu \mathrm{M}]$} & $\begin{array}{c}\text { OL induced apoptosis in HCC } \\
\text { cells via the suppression of } \\
\text { PI3K/Akt }\end{array}$ & [92] \\
\hline & HepG2 & 100,200 and $300 \mu \mathrm{M}$ & $\begin{array}{l}\text { OL could control the influencing } \\
\text { of pro-nerve growth factor (NGF) } \\
\text { and NGF balance via affecting } \\
\text { MMP-7 activity without affecting } \\
\text { the gene expression of NGF in } \\
\text { HCC. }\end{array}$ & [93] \\
\hline & $\begin{array}{l}\text { LNCaP human prostate cancer } \\
\text { androgen-responsive and DU145 } \\
\text { androgen non-responsive cell lines }\end{array}$ & 100 and $500 \mu \mathrm{M}$ & $\begin{array}{l}\text { OL reduced cell viability and } \\
\text { induced thiol group modification }\end{array}$ & [94] \\
\hline & $\begin{array}{l}\text { TCP-1 and BCPAP thyroid tumor cell } \\
\text { line }\end{array}$ & 10,50 , and $100 \mu \mathrm{M}$ & $\begin{array}{l}\text { OL was able to inhibit in vitro } \\
\text { thyroid cancer cell proliferation } \\
\text { acting on the growth-promoting } \\
\text { signal pathway }\end{array}$ & [95] \\
\hline & $\begin{array}{l}\text { HeLa human cervical carcinoma cell } \\
\text { line }\end{array}$ & 150 and $200 \mu \mathrm{M}$ & $\begin{array}{c}\text { OL-induced apoptosis was } \\
\text { activated by the JNK/SPAK signal } \\
\text { pathway }\end{array}$ & [96] \\
\hline & $\begin{array}{l}\text { SH-SY5Y human neuroblastoma cell } \\
\text { line }\end{array}$ & $350 \mu \mathrm{M}$ & $\begin{array}{l}\text { OL caused cell cycle arrest by } \\
\text { down-regulating CyclinD1, } \\
\text { CyclinD2, CyclingD3, CDK4, and } \\
\text { CDK6 and up-regulating p53 and } \\
\text { CDKN2A, CDKN2B, CDKN1A } \\
\text { gene expressions. OL also } \\
\text { induced apoptosis }\end{array}$ & [97] \\
\hline & $\begin{array}{l}\text { U251 and A172 human glioma cancer } \\
\text { cell lines }\end{array}$ & 0,200 , and $400 \mu \mathrm{M}$ & $\begin{array}{l}\text { OL inhibited cell viability and } \\
\text { reduced the expression levels of } \\
\text { MMP-2 and MMP-9. In addition, } \\
\text { a specific PI3K inhibitor enhanced } \\
\text { the pro-apoptotic and } \\
\text { anti-invasive effects induced by } \\
\text { OL }\end{array}$ & [98] \\
\hline & $\begin{array}{c}\text { HNE1 and HONE1 human } \\
\text { nasopharyngeal carcinoma (NPC) cell } \\
\text { lines }\end{array}$ & 0 and $200 \mu \mathrm{M}$ & $\begin{array}{l}\text { OL treatments reduced the activity } \\
\text { of the HIF- } 1 \alpha \text {-miR- } 519 \mathrm{~d}-\mathrm{PDRG} \\
\text { pathway, which is essential to the } \\
\text { radio-sensitizing effect of OL }\end{array}$ & [99] \\
\hline & $\begin{array}{l}\text { A549 human non-small cell lung } \\
\text { cancer (NSCLC) }\end{array}$ & {$[0-200 \mu \mathrm{M}]$} & $\begin{array}{c}\text { OL caused a decrease in } \\
\text { mithocondrial membrane } \\
\text { potential, increase in Bax/Bcl } 2 \\
\text { ratio, release of mithocondrial } \\
\text { cytochrome } \mathrm{C} \text {, and activation of } \\
\text { caspase } 9 \text { and caspase } 3\end{array}$ & [100] \\
\hline & H1299 lung cancer cell line & {$[0-200 \mu \mathrm{M}]$} & $\begin{array}{l}\text { OL-induced apoptosis via the } \\
\text { mitochondrial apoptotic cascade } \\
\text { was activated by the p38 MAPK } \\
\text { signaling pathway in H1299 cells }\end{array}$ & [101] \\
\hline & $\begin{array}{l}\text { A549 and BEAS-2B human } \\
\text { noncancerous cell line }\end{array}$ & 50 and $150 \mu \mathrm{M}$ & $\begin{array}{l}\text { OL induced apoptosis in A549 } \\
\text { cells }\end{array}$ & [102] \\
\hline & $\begin{array}{l}\text { MIA PaCa-2, BxPC-3, and CFPAC-1 } \\
\text { pancreatic cancer and HPDE } \\
\text { non-tumorigenic pancreas cell lines }\end{array}$ & $200 \mu \mathrm{M}$ & $\begin{array}{l}\text { OL arrested cell cycle, increased } \\
\text { the Bax/Bcl-2 ratio, increased the } \\
\text { activation of caspase } 3 / 7 \text {, and } \\
\text { induced apoptosis in MIA-PaCa- } 2\end{array}$ & [103] \\
\hline & A375 human melanoma cell line & {$[250-500 \mu \mathrm{M}]$} & $\begin{array}{c}\text { OL was able to stimulate } \\
\text { apoptosis }(500 \mu \mathrm{M}) \text {, while at a } \\
\text { dose of } 250 \mu \mathrm{M} \text { it affected cell } \\
\text { proliferation and induced the } \\
\text { down-regulation of the pAkt/pS6 } \\
\text { pathway }\end{array}$ & [104] \\
\hline & $\begin{array}{l}\text { OE-19 human esophagical cancer (EC) } \\
\text { cell line }\end{array}$ & $200 \mu \mathrm{M}$ & $\begin{array}{l}\text { OL inhibited the growth of EC } \\
\text { cells as well as inhibiting HIF-1 } \alpha \\
\text { and up-regulating BTG } \\
\text { anti-proliferation F factor } 3 \text { (BTG3) } \\
\text { expressions }\end{array}$ & [105] \\
\hline
\end{tabular}


Table 1. Cont.

\begin{tabular}{|c|c|c|c|c|}
\hline $\begin{array}{l}\text { Phenolic } \\
\text { Compound }\end{array}$ & Cell Line & Concentration & Effects & Reference \\
\hline & $\begin{array}{l}\text { 143B human osteosarcoma (OS) cell } \\
\text { line }\end{array}$ & $100 \mu \mathrm{M}$ & $\begin{array}{c}\text { OL showed alone and in } \\
\text { combination with } \\
\text { 2-methoxyestradiol a potent } \\
\text { anti-cancer potential in highly } \\
\text { metastatic OS cell }\end{array}$ & [106] \\
\hline & $\begin{array}{l}\text { AGS Human gastric adenocarcinoma } \\
\text { cell line }\end{array}$ & {$[0-1000 \mu \mathrm{g} / \mathrm{mL}]$} & $\begin{array}{l}\text { Magnetic nano-OL could trigger } \\
\text { apoptosis in the AGS cell line }\end{array}$ & [107] \\
\hline OL-aglycone & $\begin{array}{l}\text { SH-SY5Y and RIN-5F insulinoma cell } \\
\text { lines }\end{array}$ & $100 \mu \mathrm{M}$ & $\begin{array}{l}\text { OL-aglycone triggered autophagy } \\
\text { in cultured cells through the } \\
\mathrm{Ca}^{+} \text {-CAMKK } \beta-\text { AMPK axis. }\end{array}$ & [108] \\
\hline \multirow{13}{*}{ OLE } & $\begin{array}{l}\text { HT29 and HCT-116 human colon } \\
\text { adenocarcinoma cell line }\end{array}$ & $1,2,5$, and $10 \mu \mathrm{g} / \mathrm{mL}$ & $\begin{array}{l}\text { OLE produced an inhibition of } \\
\text { AP1 activity and cyclooxygenase } 2 \\
\text { (COX2) expression in HT29 cells }\end{array}$ & [109] \\
\hline & $\begin{array}{l}\text { MDA-MB-231, MCF-7, and PC3 } \\
\text { prostate cancer cell lines }\end{array}$ & {$[0-20 \mu \mathrm{M}]$} & $\begin{array}{l}\text { OLE inhibited the proliferation, } \\
\text { migration, and invasion of the } \\
\text { epithelial human breast and } \\
\text { prostate cancer cell lines and } \\
\text { demonstrated anti-angiogenic } \\
\text { activity }\end{array}$ & [110] \\
\hline & BT-474, MDA-MB-231, and MCF-7 & {$[0-60 \mu \mathrm{M}]$} & $\begin{array}{c}\text { OLE reduced the c-Met kinase } \\
\text { activity, cell growth, migration, } \\
\text { and invasion of breast cancer cells } \\
\text { and induced G1 cell cycle arrest } \\
\text { and apoptosis, as well as, } \\
\text { inhibited c-Met-dependent } \\
\text { signaling }\end{array}$ & [111] \\
\hline & MDA-MB-231 & {$[0-10 \mu \mathrm{M}]$} & $\begin{array}{c}\text { OLE showed strong } \\
\text { anti-proliferative and } \\
\text { down-regulated the expression of } \\
\text { phosphorylated mTOR }\end{array}$ & [112] \\
\hline & BT-474 & {$[0-100 \mu \mathrm{g} / \mathrm{mL}]$} & $\begin{array}{l}\text { OLE reduced breast cancer } \\
\text { progression and locoregional } \\
\text { recurrence models }\end{array}$ & [113] \\
\hline & MDA-MB-231 & $5 \mathrm{mg} / \mathrm{mL}$ & $\begin{array}{l}\text { OLE was able to control breast } \\
\text { cancer progression }\end{array}$ & [114] \\
\hline & BT-474 and MDA-MB-231 & {$[0-200 \mu \mathrm{M}]$} & $\begin{array}{l}\text { OLE with the dual HER2/EGFR } \\
\text { inhibitor, LP, induced synergistic } \\
\text { tumor growth inhibition }\end{array}$ & [115] \\
\hline & MCF-10A, MDA-MB-231, and MCF-7 & 1,10 , and $20 \mu \mathrm{M}$ & $\begin{array}{l}\text { OLE could be responsible for the } \\
\text { selective activation of } \\
\text { TRCP6-dependent } \mathrm{Ca}^{2+} \text { influx } \\
\text { and TRCP6 down-regulation at } \\
\text { low } \mu \mathrm{M} \text { concentrations }\end{array}$ & [116] \\
\hline & $\begin{array}{l}\text { Huh-7, HepG2, and HCCLM3 HCC } \\
\text { cancer cell lines }\end{array}$ & {$[0-80 \mu \mathrm{M}]$} & $\begin{array}{c}\text { OLE inhibited proliferation and } \\
\text { cell cycle progression and also } \\
\text { inhibited HCC cell migration and } \\
\text { invasion }\end{array}$ & [117] \\
\hline & Huh-7, HepG2, and HCCLM3 & 5 and $10 \mu \mathrm{M}$ & $\begin{array}{l}\text { OLE reduced cell proliferation } \\
\text { and increased cell death }\end{array}$ & [118] \\
\hline & $\begin{array}{l}\text { U937 hystocytic lymphoma cancer } \\
\text { cell line }\end{array}$ & $30 \mu \mathrm{M}$ & $\begin{array}{l}\text { OLE significantly inhibited the } \\
\text { expression of Hsp90, a chaperone } \\
\text { with a key role in cancer and } \\
\text { neurodegeneration }\end{array}$ & [119] \\
\hline & $\begin{array}{l}\text { A375: A2058; HUVEC and HaCat } \\
\text { cancer cell lines }\end{array}$ & {$[0-60 \mu \mathrm{M}]$} & $\begin{array}{c}\text { OLE suppressed STAT3 } \\
\text { phosphorylation, decreased } \\
\text { STAT3 nuclear localization, and } \\
\text { inhibited STAT3 transcriptional } \\
\text { activity }\end{array}$ & [120] \\
\hline & $\begin{array}{l}\text { Inmortalized human keratinocytes } \\
\text { stimulated with epidermal growth } \\
\text { factor }\end{array}$ & {$[0-100 \mu \mathrm{M}]$} & $\begin{array}{l}\text { OLE promoted the inhibition of } \\
\text { ERK and Akt phosphorylation } \\
\text { and the suppression of B-raf } \\
\text { expression }\end{array}$ & [121] \\
\hline
\end{tabular}


Table 1. Cont

\begin{tabular}{|c|c|c|c|c|}
\hline $\begin{array}{l}\text { Phenolic } \\
\text { Compound }\end{array}$ & Cell Line & Concentration & Effects & Reference \\
\hline \multirow{3}{*}{ OLA } & $\begin{array}{l}\text { Inmortalized human keratinocytes } \\
\text { stimulated with epidermal growth } \\
\text { factor }\end{array}$ & {$[0-100 \mu \mathrm{M}]$} & $\begin{array}{l}\text { OLA promoted the inhibition of } \\
\text { Erk and Akt phosphorylation and } \\
\text { the suppression of B-raf } \\
\text { expression }\end{array}$ & [121] \\
\hline & $\begin{array}{l}\text { HL60 human promyelocytic leukemia } \\
\text { cell line }\end{array}$ & {$[0-10 \mu \mathrm{M}]$} & $\begin{array}{c}\text { OLA reduced the DNA damage at } \\
\text { concentrations as low as } 1 \mu \mathrm{M} \\
\text { when co-incubated in the medium } \\
\text { with } \mathrm{H}_{2} \mathrm{O}_{2}\end{array}$ & [43] \\
\hline & $\begin{array}{l}\text { NCI-H929; RPMI-8226; U266; MM1S } \\
\text { and IIN3 human MM cancer cell lines }\end{array}$ & $2.5,5$ and $10 \mu \mathrm{M}$ & $\begin{array}{l}\text { OLA elicited significant antitumor } \\
\text { activity by promoting cell cycle } \\
\text { arrest and apoptosis either with a } \\
\text { simple agent or in combination } \\
\text { with Carfilzomib }\end{array}$ & [122] \\
\hline
\end{tabular}

Table 2. Most recent in vivo studies that corroborate the important role of secoiridoids from the olive tree in the control and progression of different types of cancer.

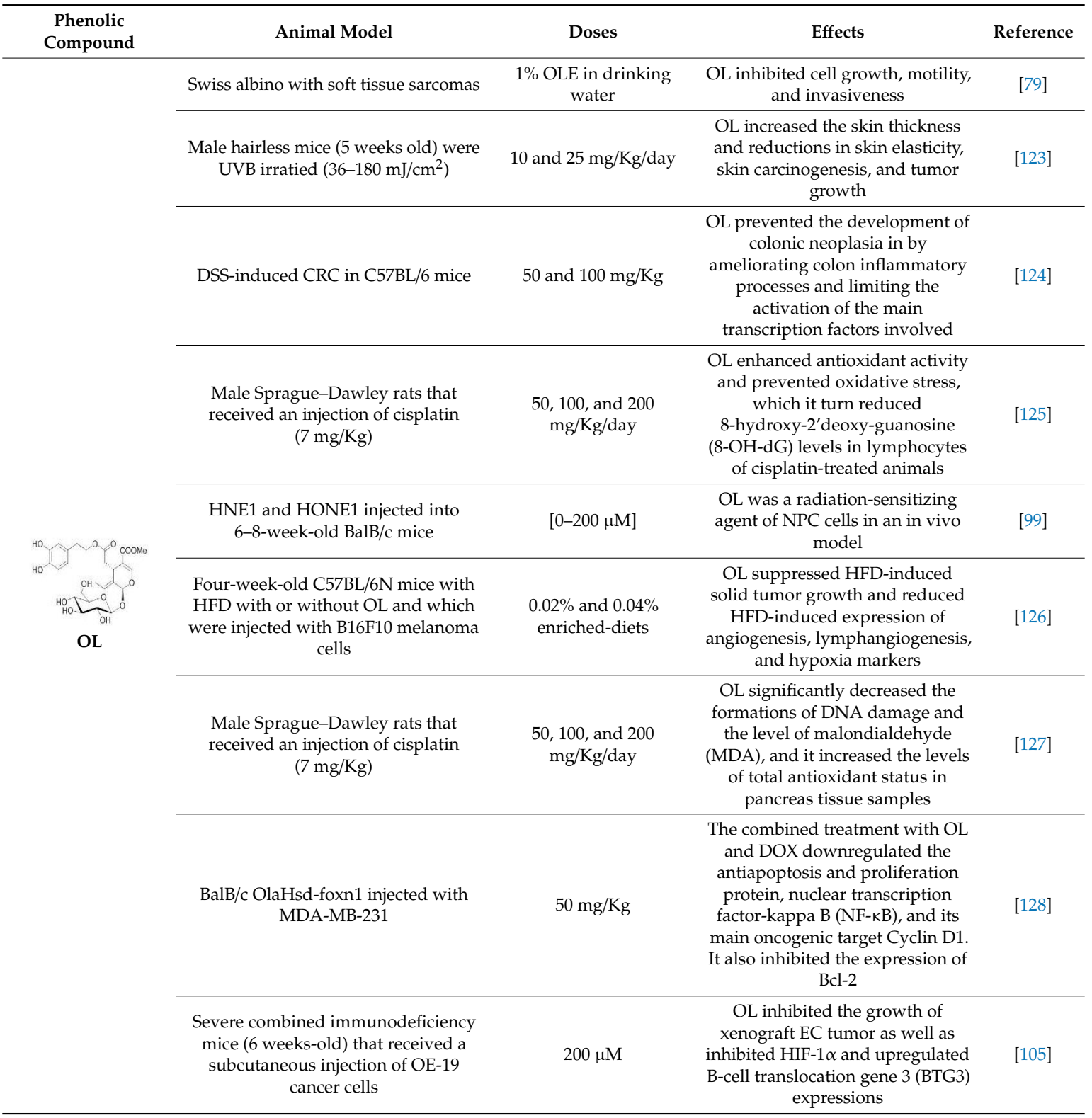


Table 2. Cont.

\begin{tabular}{|c|c|c|c|c|}
\hline $\begin{array}{l}\text { Phenolic } \\
\text { Compound }\end{array}$ & Animal Model & Doses & Effects & Reference \\
\hline OL-aglycone & $\begin{array}{l}\text { Transgenic hemizygous CRND8 mice } \\
\text { harboring a double-mutant gene of } \\
\text { APP695 and wild-type control } \\
\text { lettermates with } 4 \text { and } 10 \text { months of } \\
\text { age }\end{array}$ & $100 \mu \mathrm{M}$ & $\begin{array}{l}\text { In OL-fed animals, there was a } \\
\text { reduction of phospho-mTOR } \\
\text { immunoreactivity and } \\
\text { phosphorylated mTOR substrate } \\
\text { p70 S6K levels }\end{array}$ & [108] \\
\hline \multirow{3}{*}{ OLE } & Swiss albino mice (6 weeks old) & $10 \mathrm{mg} / \mathrm{Kg} /$ day & $\begin{array}{l}\text { OLE reduced breast cancer } \\
\text { progression and locoregional } \\
\text { recurrence models }\end{array}$ & [113] \\
\hline & $\begin{array}{c}\text { Female athymic nude mice } \\
\left(\text { Foxn } 1^{\text {nu }} / \text { Foxn } 1^{+}\right)(4-5 \text { weeks-old }) \\
\text { inyected with BT-474 and } \\
\text { MDa-MB-231 }\end{array}$ & $10 \mathrm{mg} / \mathrm{Kg} /$ day & $\begin{array}{l}\text { OLE inhibited locoregional } \\
\text { recurrence in luminal } \mathrm{HER}^{2+} / \mathrm{ER}^{+} \\
\text {BT- } 474 \text { tumors }\end{array}$ & [129] \\
\hline & $\begin{array}{l}\text { Orthotopic tumor model of HCC in } \\
\text { BalB } / \mathrm{c} \text { mice }\end{array}$ & 0,5 and $10 \mathrm{mg} / \mathrm{Kg} /$ day & $\begin{array}{l}\text { OLE suppressed tumor growth } \\
\text { and impeded HCC metastasis in } \\
\text { an in vivo lung metastasis model. } \\
\text { OLE inhibited STAT3 activation } \\
\text { and increased the activity of } \\
\text { protein tyrosine hosphatase }\end{array}$ & [117] \\
\hline
\end{tabular}

OL is the most abundant of the phenolic compounds in olives. It could scavenge reactive oxygen and nitrogen species as well as promote nitric oxide (NO) production in macrophages. In fact, it has been postulated that OL may be the major factor responsible for the beneficial effects of the Mediterranean diet against tumor growth [79].

There are several studies describing the potential role of OL in breast cancer. For example, researchers have established the beneficial effects of OL in MCF-7, MCF-10A, and MDA-MB-231 human breast cancer cells where OL was able to decrease the expression of histone deacetylase II (HDAC2), HDAC3, and HDAC4, induce apoptosis, and retard cell migration and invasion in a dose-dependent manner [88,89]. Besides, OL produced tissue inhibitors of metalloproteinases (TIMPs) overexpression and metalloproteinases (MMPs) genes down-regulation, which could help in the prevention of breast cancer metastasis [82]. Similarly, OL treatment reduced MDA-MB-231 cell viability in a dose-dependent manner and significantly suppressed hepatocyte growth factor (HGF) and 3-methyladenine (3-MA) inducing cell migration and invasion [90].

In human HT29 colon adenocarcinoma cell line, OL limited the growth and induced apoptosis via p53 pathway activation, adapting the hypoxia-inducible factor $1-\alpha$ (HIF-1 $\alpha$ ) response to hypoxia [81]. In addition, OL induced anti-proliferative and pro-apoptotic effects in a range of doses from 0 to $100 \mu \mathrm{M}$ in HT29 cells [80].

On the other hand, OL induced apoptosis in hepatocellular carcinoma (HCC) via the suppression of the phosphatidylinositol 3-kinase and protein kinase B (PI3K/Akt) pathway [130]. In fact, in combination with other compounds, such as cisplatin, OL could lead to more effective chemotherapeutic combination against HCC [130]. Similarly, in HeLa human cervical carcinoma cells, OL-induced apoptosis was activated by the c-Jun N-terminal kinase (JNK)/Ste20-like proline alanine rich kinase (SPAK) signal pathways [96], and both OL and its peracetylated derivative were able to inhibit thyroid cancer cell proliferation acting on the growth-promoting signal pathway in the TCP- 1 and BCPAP thyroid tumor cell lines [95]. Likewise, OL reduced cell viability in human prostate cancer androgen-responsive cells [94], induced autophagy and caused cell cycle arrest in SH-SY5Y human neuroblastoma cells [97,108], and reduced cell viability in U251 and A172 human glioma cancer cells [98].

Similarly, there are several in vivo studies that have showed the beneficial effects of OL in different cancer models. For example, Giner et al. have demonstrated that OL prevented the development of colonic neoplasia in dextran sulfate sodium (DSS)-induced colorrectal cancer (CRC) in mice by ameliorating colon inflammatory processes [124]. Besides, there was a relation between the consumption of a high-fat diet (HFD) and the development of solid tumors, which was satisfactorily suppressed with OL-enriched diets reducing the HFD-induced expression of angiogenesis, lymphangiogenesis, 
and hypoxia markers [126]. Elamin et al. have shown that OL and doxorubicin (DOX) combined treatment down-regulated the antiapoptosis and proliferation protein in a murine model of breast cancer [83].

OLE is a bioactive micronutrient in the Mediterranean diet that may be associated with positive findings in some epidemiological studies that suggest a fewer incidences of breast, colon cancer, and other malignancies compared to western and other populations. There are several studies to enhance the beneficial role of OLE in this type of disease (Tables 1 and 2). In fact, authors believe that consuming more EVOO with high OLE content is a prudent dietary approach to prevent cancer with the caveat that dietary oils convey calories and consequently other caloric sources will have to yield to avoid obesity [131]. OLE is a unique tyrosine-protein kinase Met (c-MET) inhibitor for the control of breast cancer progression and loco regional recurrence [113,114]. The combination of OLE with lapatinib (LP) treatment would allow the use of reduced dose of targeted therapies such as LP, which would reduce future resistance emergence and drug toxicity while maintaining maximal therapeutic activity [115]. Besides, OLE has been able to reduce c-MET kinase activity, cell growth, and the migration and invasion of breast cancer cells; induce G1 cell cycle arrest and apoptosis; as well as inhibit c-MET-dependent signaling in cultured breast cancer cells and tumorigenicity in in vivo murine models [111].

OLE showed the capacity to inhibit breast cancer locoregional recurrence in luminal $\mathrm{HER}^{2+} / \mathrm{ER}^{+}$ BT-474 tumors. The prevention of tumor recurrence was associated with the down-regulation of MET and $\mathrm{HER}^{2}$ receptors and suppression of receptor activation [129]. OLE showed a strong anti-proliferative role against several breast cancer cell lines; for example, OLE was able to down-regulate the expression of phosphorylated mammalian target of rapamycin (mTOR) in metastatic MDA-BD-231 breast cancer cell lines [112] and inhibit the proliferation, migration, and invasion of the epithelial human breast cancer and prostate cancer cell lines (MCF7; MDA-BD-231; and PC3). In addition, LeGendre et al. demonstrated that OLE selectively and rapidly induces cell death in cancer cells without being cytotoxic to noncancerous cells. OLE induced cell death by entering the lysosome and inhibiting acid sphingomyelinase (ASM) activity, which induced lyposomal membrane permeabilization (LMP). Even the consumption of $10 \mathrm{mg} / \mathrm{Kg}$ oral daily OLE water emulsion treatment significantly suppressed the MDA-BD-231 tumor growth by $90 \%$ [132].

Multiple myeloma (MM) is another disease that would be approached with OLE treatment. MM is a plasma cell malignancy that causes devastating bone destruction by activating osteoclasts in the bone marrow milieu. OLE produced the inhibition of macrophage inflammatory 1 alpha (MIP- $\alpha)$ expression and secretion in MM cells proliferation by inducing the activation of apoptosis mechanisms and by down-regulating extracellular signal-regulated kinase (ERK) $1 / 2$ and protein kinase B (Akt) signal transduction pathways [133]. Besides, OLE was able to inhibit hepatocellular cancer tumor growth and metastasis by preventing signal transducer and activator of transcription (STAT) 3 in in vitro and in vivo models. In fact, OLE inhibited proliferation and cell cycle progression in different HCC cell lines, and it also inhibited HCC cells migration and invasion in in vitro models [117].

OLA, also known as 3,4-(dihydrophenyl) ethanol (3,4-DHPEA-EDA) has antioxidant, anti-inflammatory, and anti-microbial activities well documented in previous studies, but its effects on tumor biology are still poorly defined [122]. Particularly, published studies reporting the beneficial properties of OLA in the development of several cancers have been summarized in Tables 1 and 2. In this sense, OLA was able to reduce the DNA damage in HL60 promyelocytic leukemia cells when co-incubated with $\mathrm{H}_{2} \mathrm{O}_{2}$ in the medium [43] and also presented similar effects to OLE in the reduction of viability and migration of non-melanoma skin cancer cells and in the inhibition of proliferation of ERK and Akt phosphorylation and particularly through the reduction of B-Raf expression [121]. Likewise, OLA reduced the viability of MM primary samples and cell lines even in the presence of bone marrow stromal cells (BMSCs) [84]. 


\subsection{Olive Tree Secoiridoids and Cardiovascular Diseases}

The Global Burden of Disease indicates that cardiovascular diseases are still the main cause of global death, representing about 31\% of total deaths in the world in 2015 [134]. These pathologies affect heart and vessels, as coronary heart disease, cerebrovascular disease, peripheral arterial disease, and pulmonary embolism, among others [135]. There is evidence that suggests a possible link between inflammation, endothelial dysfunction, and cardiovascular diseases are increased by oxidative stress. Oxidative stress plays a critical role in the development and progression of atherosclerosis and their complications including characteristics affections such as the regulation of vascular tone, vascular smooth muscle growth, monocyte adhesion, platelet function, and fibrinolytic activity, among others [136]. In terms of risk factors, the three world leading factors for cardiovascular diseases are (i) high systolic blood pressure (SBP), (ii) smoking, and (iii) high body mass index (BMI). Proper nutrition habits and healthy lifestyle play a major preventive role [134].

It has been widely reported that secoiridoids play a beneficial role against cardiovascular diseases based on their antioxidant and anti-inflammatory activities. Interesting studies performed with animal and cell models suggest that secoiridoids intake may be beneficial for the prevention and adjuvant treatment of such diseases (Tables 3 and 4). Catalán et al. confirmed changes at proteomic level in cardiovascular tissues (aorta and heart tissues), down-regulating proteins related to the proliferation and migration of endothelial cells and occlusion of blood vessels in the aorta, and proteins related to heart failure in heart tissue in Wistar rats fed a secoiridoids-enriched diet [137].

Table 3. Beneficial effects of secoiridoids from the olive tree in the control and progression of different types of cardiovascular diseases: in vitro studies.

\begin{tabular}{|c|c|c|c|c|}
\hline $\begin{array}{l}\text { Phenolic } \\
\text { Compound }\end{array}$ & Cell Line & Concentration & Effects & Reference \\
\hline \multirow{3}{*}{$\mathrm{OL}$} & Healthy human LDL & $10 \mathrm{mM}$ & $\begin{array}{c}\text { OL inhibited LDL levels, lipid } \\
\text { peroxides, malondial } \\
\text { dehydelysine, } 4 \text {-hydroxynonenal } \\
\text { lysine adducts expression }\end{array}$ & [138] \\
\hline & LPS-stimulates mouse macrophages & & $\begin{array}{l}\text { OL reduced superoxide anion } \\
\text { generation, neutrophils } \\
\text { respiratory burst, and } \\
\text { hypochlorous acid }\end{array}$ & [139] \\
\hline & $\begin{array}{l}\text { Endothelial progenitors cells (CD31+ } \\
\text { and VEGFR- } 2^{+} \text {) }\end{array}$ & {$[1-10 \mu \mathrm{M}]$} & $\begin{array}{l}\text { OL reduced senescent cells and } \\
\text { reactive oxygen species (ROS) } \\
\text { formation; restoration of } \\
\text { migration, adhesion, tube } \\
\text { formation, and the up-regulation } \\
\text { of Nrf- } 2 \text { and HO-1 expressions. }\end{array}$ & [140] \\
\hline OL-aglycone & Mouse atrial myocites HL-1 & $60 \mathrm{mM}$ & $\begin{array}{l}\text { OL-aglycone inhibited } \\
\text { tranthyretin toxicity }\end{array}$ & [142] \\
\hline & Human neutrophils and monocytes & {$[1-10 \mu \mathrm{M}]$} & $\begin{array}{l}\text { OLA proved to be stronger in the } \\
\text { reduction of } \\
\text { formyl-met-leu-phenylalanine and } \\
\text { phorbol-myristate-acetate-induced } \\
\text { oxidative bursts in neutrophils } \\
\text { and myeloperoxidase release }\end{array}$ & [32] \\
\hline OLA & Human neutrophils & 50 and $100 \mathrm{mM}$ & $\begin{array}{l}\text { OLA reduced elastase release, } \\
\text { IL-8, MMP-9, and NEP activity }\end{array}$ & [143] \\
\hline
\end{tabular}


Table 4. Beneficial effects of secoiridoids from the olive tree in the control and progression of different types of cardiovascular diseases: in vivo and clinical studies.

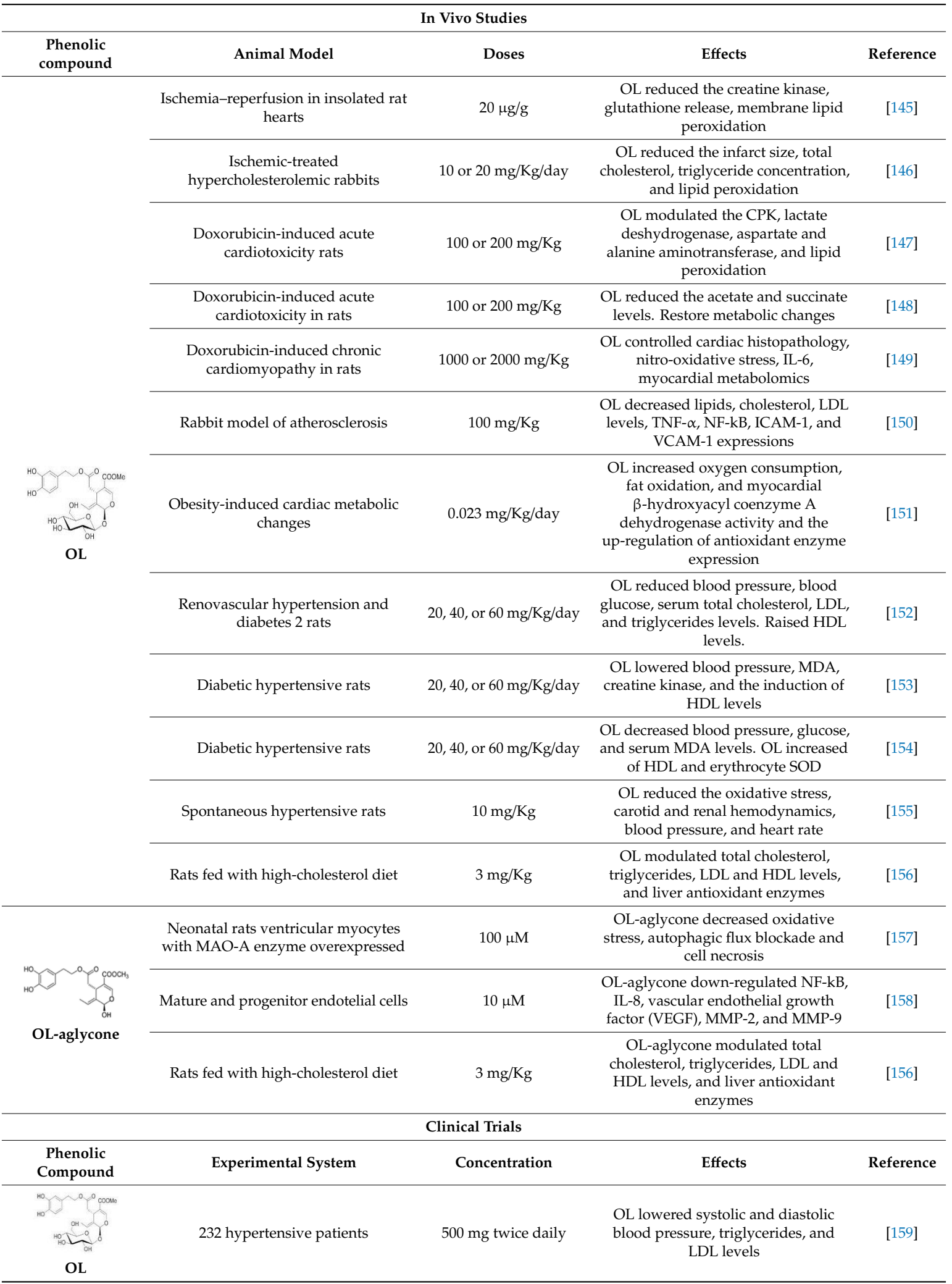

One of the best-documented cardiovascular protector secoiridoids is OL. OL inhibited in a dose-dependent manner the copper sulfate-induced oxidation of LDL, reducing the formation of lipid peroxides and malondhial dehydelysine and 4-hydroxynonenol-lysine adducts [138]. These data 
indicated the protection of the apoprotein layer. Additionally, OL was able to scavenge superoxide anions generated by either polymorphonuclear cells or by the xanthine/xanthine oxidase system [139]. In this line, pretreatment with $20 \mu \mathrm{g} / \mathrm{g}$ of OL before ischemia-reperfusion in isolated rats hearts resulted in a significant reduction in creatine kinase and glutathione release, supporting experimental evidences of a direct cardioprotective effect of OL [145]. More recently, Parzonko and colleagues described that OL-treated endothelial progenitors cells (type CD31+ and VEGFR-2 ${ }^{+}$) showed a decrease in the percentage of senescent cells and ROS formation and restored migration, adhesion, and tube formation. This effect was related to nuclear factor E2-related factor 2 (Nrf2) and heme oxigenase-1 (HO-1) expressions [140] (Table 3).

Relating to animal models, Andreadou and co-workers have developed several in vivo experimental models with OL treatment, defining the potential effect of this secoiridoid as a cardioprotector. Ischemia-treated rabbits fed with 10 or $20 \mathrm{mg} / \mathrm{Kg} /$ day OL-supplemented diets showed a reduction in infarct size, total cholesterol, and triglyceride concentrations [146]. Similarly, OL administrated via intravenous decreased some markers of cardiovascular disease in DOX-induced acute cardiotoxic rats such as creatine phosphokinase (CPK), lactate deshydrogenase, aspartate and alanine aminotransferase, and lipid peroxidation in myocardial tissue [147]. Completing this study, these authors revealed that OL down-regulated acetate and succinate levels and restored metabolic changes to normal levels in myocardial tissue [148]. Finally, Andreadou et al. concluded that OL administration could also prevent cardiomyopathy [149] (Table 4).

Concerning studies of atherosclerosis, OL could decreased serum lipids and tumor necrosis factor alpha (TNF- $\alpha$ ) levels, which was accompanied by a down-regulation of monocyte chemostactic protein-1 and vascular cell adhesion molecule [150]. Ebaid et al. studied the effects of OL intake in obesity-induced cardiac metabolic changes. They found that an OL diet showed an increase of oxygen consumption, fat oxidation, and myocardial $\beta$-hydroxyacyl coenzyme A dehydrogenase activity and a reduction in the levels of lipid hydroperoxide and up-regulation of antioxidant enzyme confirmed that OL improved myocardial oxidative stress in standard-fed conditions [151].

With regard to OL antihypertensive effects, there are several studies performing different animal models. In this line, diabetic and hypetensive rats receiving 20, 40, or $60 \mathrm{mg} / \mathrm{Kg} /$ day of OL presented significantly reduced blood pressure, blood glucose, serum total cholesterol, LDL, triglyceride, MDA, coronary effluent creatine kinase, and coronary resistance. The animals also had high-density lipoprotein (HDL), erythrocyte SOD, left ventricular develop pressure, rate of rise, and rate of decrease of ventricular pressure [152-154]. Antihypertensive activity has also been supported by Ivanov et al., who reported significant changes in carotid and renal hemodynamics, reducing cardiovascular risk and improving vascular resistance in spontaneous hypertensive rat oxidative stress [155].

Regarding lipid regulation, the administration of OL and its aglycone form significantly down-regulated the serum levels of total cholesterol, triglycerides, and LDL and up-regulated HDL and liver antioxidant enzymes in Wistar rats fed a cholesterol-rich diet. These results demonstrated that secoiridoids administration could control the lipid peroxidation process, enhancing antioxidant enzyme activity [156].

The clinical trials of the effects of secoiridoids on cardiovascular diseases are scant. In this regard, 232 hypertension patients were involved in a clinical study subjected to a 500-mg oral dose of an OL-enriched extract administration twice daily for 8 weeks. The patients presented a significant reduction of systolic and diastolic blood pressure as well as the levels of triglycerides and LDL $[159,160]$ (Table 4). Stock and colleagues measured cholesterol efflux capacity from free cholesterol-enriched macrophages to apolipoprotein B-depleted serum as the cholesterol acceptor in patients with coronary artery disease. OL showed a positive behavior against LDL oxidation, promoting cholesterol efflux and suggesting preventive effects against coronary artery diseases and enhanced atheroprotective actions [161].

According to OL aglycone, only few studies have been carried out. Dell'agli et al. described that OL aglycone exerted a modulation in early atherogenesis, reducing cell surface expressions of 
intracellular and vascular cell adhesion molecules (ICAM-1 and VCAM-1) in human umbilical vascular endothelial cells [141]. Similar to OL, the aglycone form was studied in rats fed with a cholesterol-rich diet by Jemai el at. The results suggested that the hypocholesterolemic effect of OL-aglycone might be due to its abilities to lower serum total cholesterol, triglycerides, and LDL cholesterol levels, slowing the lipid peroxidation process and enhancing SOD and CAT antioxidant enzyme activities, exhibiting a cardioprotective role against lipid oxidation and cholesterol efflux [156].

More recently, Leri et al. reported that OL-aglycone was able to reduce transthyretin toxicity in mouse atrial myocytes, so it could be used as treatment for severe cardiac symptoms [142]. In addition, Miceli and coworkers explored the effects of OL-aglyone in myocytes with an overexpression of monoamine oxidase-A (MAO-A), which is an enzyme that causes oxidative stress, autophagy flux blockade, and cell necrosis as a model of cardiac stress characterized by autophagy dysfunction. They observed that OL-aglycone counteracted the cytotoxic MAO-A effects [157]. Margheri et al. also reported the effects of OL aglycone on capillary morphogenesis induced by MRC5 fibroblast "senescense associated secretory phenotype" and progenitor endothelial cells, establishing that this secoiridoid could modulate angiogenesis indirectly on senescent fibroblasts [158] (Table 4).

To date, OLE cardioprotective activity has been slightly investigated. Even so, some authors defend its cardioprotective property based on its capacity to inhibit COX-1 and COX-2 expression. It is well-known that thrombotic and cardiovascular disorders are linked to an imbalance in prostanoid homeostasis, particularly prostaglandin or thromboxane production, which are involved in vasodilatation or vasoconstriction, respectively, and platelet aggregation [162]. OLE has exerted strong inhibitory effects on COX-1 and COX-2 in several studies $[50,163,164]$; nevertheless, future studies are needed to confirm the property of OLE in cardiovascular disorders (Table 3).

The cardiovascular protection effects of OLA were tested in vitro in human neutrophils and monocytes. This compound was able to scavenge $\mathrm{O}_{2}{ }^{-}, \mathrm{H}_{2} \mathrm{O}_{2}$, and NO levels, among other parameters, which are implicated in tissue injury and chronic diseases, as atherosclerosis [32,165]. In a similar work, Czerwinska et al. studied the capacity of OLA on neutral endopeptidase (NEP) activity and other functions of human neutrophils, such as elastase, MMP-9 and interleukin (IL)-8 production, which was markedly increased in patients with myocardial infarction [32]. The authors concluded that OLA could play a role in the cardiovascular protective effects described by olive oil by inhibiting NEP activity, adhesion molecules expression, and elastase release. Likewise, Filipek and colleagues showed that OLA increased CD163 expression in human macrophages, supporting the significant role in attenuation of plaque destabilization induced by hemorrhages [144]. Later, these authors reported the beneficial effects of OLA in attenuating the destabilization of carotid plaque in 20 patients with hypertension. This work revealed the ability of OLA to modulate IL-10, HO-1, MMP-9, and high mobility group protein-1, which is a specific biomarker of cell lethality [166]. Thus, this compound could be potentially useful in the reduction of ischemic stroke risk. Concluding, the preventive and curative role of OLA, in terms of cardiovascular injury, could be attributed to its ability to regulate LDL oxidation and MPO activity, to reduce the expression of adhesion molecules, as angiotensin II production, and to confer protection to erythrocytes from oxidative hemolysis [33,73].

\subsection{Olive Tree Secoiridoids and Neurodegeneration}

Neurodegeneration is a process that leads to a progressive loss of structure or function of neurons, irreversible neuronal damage, death, and a common final pathway present in aging and neurodegenerative diseases. In addition, oxidative stress induced by impaired mitochondrial functions has been also reported [167]. Particularly, superoxide anion formation and the production of hydrogen peroxide are triggered by the induction of NADPH oxidase (NOX) subunit. This condition together with a high NO level, produced by the induction of inducible nitric oxide synthase (iNOS) results in the formation of peroxynitrite and nitrative stress [69]. Examples of neurodegenerative diseases include Alzheimer's disease (AD), Parkinson's disease (PD), Huntington's disease, amyotrophic lateral sclerosis, frontotemporal dementia, and the spinocerebellar ataxias [168]. These diseases represent a 
primary health problem, especially in the aging population. Powerful experimental model organisms such as the mouse, fruit fly, nematode worm, and even baker's yeast have been used for many years to explore neurodegenerative diseases and have provided key insights into these brain disorders.

Several epidemiological and observational studies support the belief that traditional alimentary regimens such as the Mediterranean diet where olive oil is the primary source of added fat is associated with improved aging and a reduced incidence of age-related diseases, including cardiovascular diseases, cancer, and cognitive decline [169]. Particularly, olive leaves and EVOO contain many functional phenolics that have been demonstrated to be able to reduce risk and offer protection against several aging and lifestyle-related diseases, including neurodegeneration, in both animal and human's models. In fact, EVOO consumption has well-documented antioxidant, anti-inflammatory, anti-proliferative, anti-carcinogenic, and antibacterial effects [170]. Among the 200 different chemical compounds detected in olive oil, quantitatively, the class of secoiridoids is the most abundant. A number of different studies investigated the effects of secoiridoids from olive trees in both in vitro and in vivo models of $A D$ and PD (Tables 5 and 6).

Table 5. In vitro studies that corroborate the effects of secoiridoids from the olive tree in different types of neurodegeneration processes.

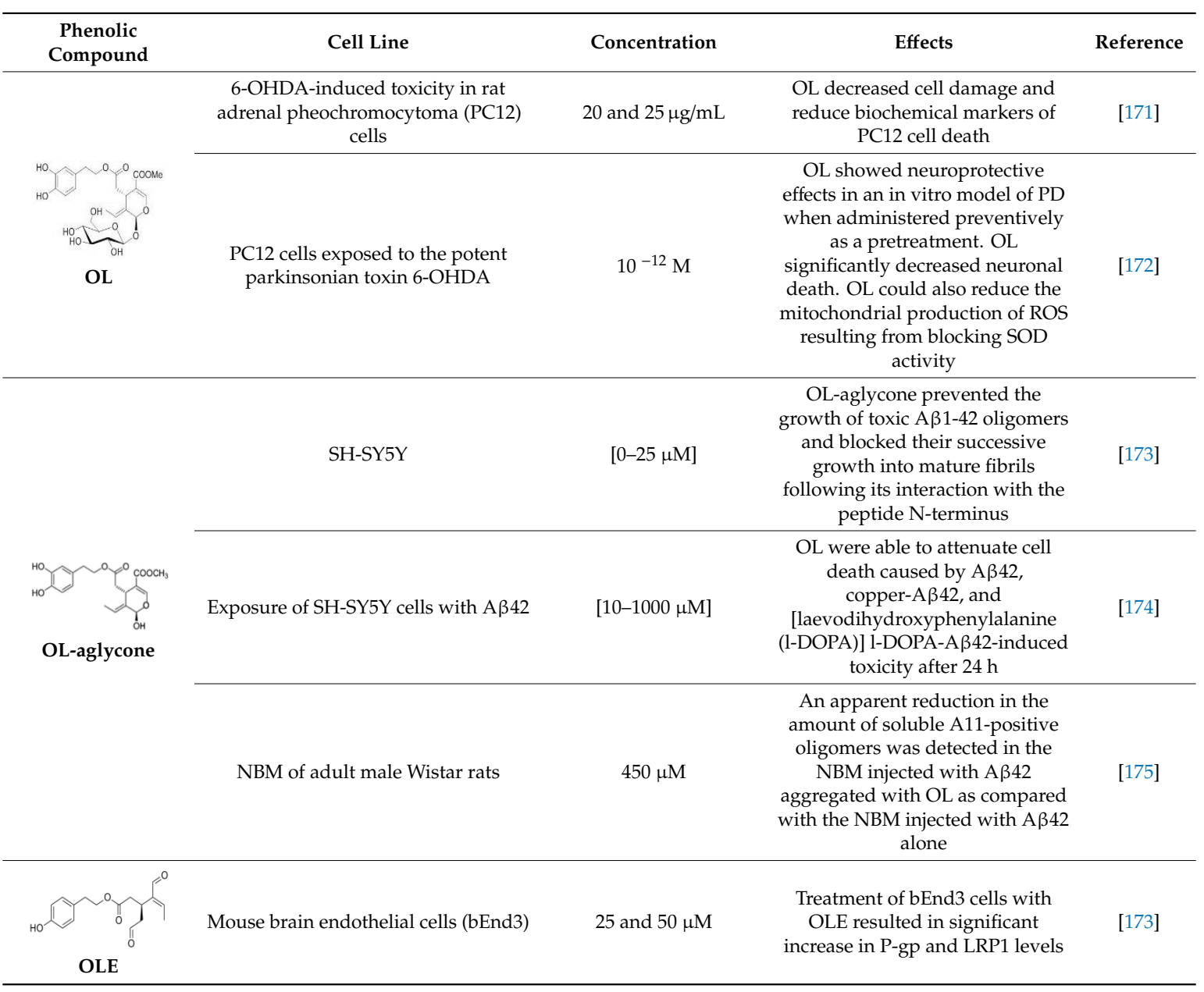


Table 6. In vivo studies that corroborate the effects of secoiridoids from the olive tree in different types of neurodegeneration processes.

\begin{tabular}{|c|c|c|c|c|}
\hline $\begin{array}{c}\text { Phenolic } \\
\text { Compound. }\end{array}$ & Animal Model & Doses & Effects & Reference \\
\hline \multirow{9}{*}{ OL-aglycone } & $\begin{array}{l}\text { Double transgenic TgCRND8 mice, a } \\
\text { model of amyloid- } § \text { deposition }\end{array}$ & $\begin{array}{l}8 \text { weeks dietary } \\
\text { supplementation of } \\
\text { OL-aglycone ( } 50 \\
\mathrm{mg} / \mathrm{Kg} \text { of diet) }\end{array}$ & $\begin{array}{c}\text { Dietary supplementation of } \\
\text { OL-aglycone strongly improved } \\
\text { the cognitive performance of } \\
\text { young/middle-aged TgCRND8 } \\
\text { mice, with respect to age-matched } \\
\text { littermates with unsupplemented } \\
\text { diet }\end{array}$ & [176] \\
\hline & Transgenic mice (APPswe/PS1dE9) & $\begin{array}{l}50 \mathrm{mg} / \mathrm{Kg} \text { of } \\
\text { OL-aglycone } \\
\text { containing olive leaf } \\
\text { extracts (OLE) from } 7 \\
\text { to } 23 \text { weeks of age. }\end{array}$ & $\begin{array}{l}\text { Treatment mice }(\mathrm{OL} \text {-aglycone }) \\
\text { were showed significantly } \\
\text { reduced amyloid plaque } \\
\text { deposition }(p<0.001) \text { in cortex } \\
\text { and hippocampus in comparison }\end{array}$ & [174] \\
\hline & $\begin{array}{l}\text { Transgenic CL2006 and CL4176 } \\
\text { strains of C. elegans }\end{array}$ & 50 and $100 \mu \mathrm{M}$ & $\begin{array}{c}\text { OL-aglycone-fed CL2006 worms } \\
\text { displayed reduced A } \beta \text { plaque } \\
\text { deposition, less abundant toxic } \\
\text { A } \beta \text { oligomers, remarkably } \\
\text { decreased paralysis, and increased } \\
\text { lifespan }\end{array}$ & [177] \\
\hline & Systemic amyloidosis murine model & $15 \mu \mathrm{M}$ & $\begin{array}{l}\text { OL-aglycone hindered amyloid } \\
\text { aggregation of } A \beta(1-42) \text { and its } \\
\text { cytotoxicity and eliminated the } \\
\text { appearance of early toxic } \\
\text { oligomers, favoring the formation } \\
\text { of stable harmless protofibrils, } \\
\text { which were structurally different } \\
\text { from the typical } A \beta(1-42) \text { fibrils }\end{array}$ & [178] \\
\hline & TgCRND8 mice & $\begin{array}{l}50 \mathrm{mg} / \mathrm{Kg} \text { of diet } \\
\text { during } 8 \text { weeks }\end{array}$ & $\begin{array}{l}\text { OL-aglycone was active against } \\
\text { glutaminylcyclase-catalyzed } \\
\text { pE3-Aß generation, reducing } \\
\text { enzyme expression and } \\
\text { interfering both with Aß42 and } \\
\text { pE3-Aß aggregation }\end{array}$ & [175] \\
\hline & TgCRND8 (Tg) mice AD & $\begin{array}{c}\text { Diet supplementation } \\
\text { with OL-aglycone at } \\
12.5 \text { or } 0.5 \mathrm{mg} \mathrm{kg-1of} \\
\text { diet }\end{array}$ & $\begin{array}{l}\text { An OL-aglycone supplementation } \\
\text { diet and the mix of polyphenols } \\
\text { were found to improve } \\
\text { significantly cognitive functions ( } p \\
<0.0001 \text { ). Aß42 and pE-3Aß } \\
\text { plaque area and number were } \\
\text { significantly reduced in the cortex }\end{array}$ & [179] \\
\hline & 5xFAD mouse model of AD & EVOO rich with OLE & $\begin{array}{l}\text { EVOO-rich OLE consumption in } \\
\text { combination with donepezil } \\
\text { significantly reduced } A \beta \text { load and } \\
\text { related pathological changes }\end{array}$ & [180] \\
\hline & TgSwDI mice & $\begin{array}{l}\text { Daily i.p. with } 5 \\
\mathrm{mg} / \mathrm{Kg} \text { OLE at } 4 \text { age of } \\
\text { months and continued } \\
\text { for } 4 \text { weeks. }\end{array}$ & $\begin{array}{c}\text { OLE significantly decreased } \\
\text { amyloid load in the hippocampal } \\
\text { parenchyma and microvessels, } \\
\text { which was associated with } \\
\text { enhanced cerebral clearance of } A \beta \\
\text { across the BBB }\end{array}$ & [181] \\
\hline & C57BL/6 wild-type male mice & $\begin{array}{l}10 \mathrm{mg} / \mathrm{Kg} \text { of OLE twice } \\
\text { daily from } 7 \text { to } 8 \text { weeks } \\
\text { of age andcontinued } \\
\text { for } 2 \text { weeks (i.p.) }\end{array}$ & $\begin{array}{l}\text { OLE enhanced clearance of } \mathrm{A} \beta \\
\text { from the brain. A significant } \\
\text { increase in the expression of P-gp } \\
\text { and LRP1 was also observed in } \\
\text { the brain microvessels }\end{array}$ & [182] \\
\hline
\end{tabular}

$\mathrm{AD}$ is characterized by the increased accumulation of intracellular neurofibrillary tangles (NFTs) of hyperphosphorylated tau protein and of extracellular $\mathrm{A} \beta$ protein deposits ( $\mathrm{\beta} \beta$ plaques) derived from amyloid precursor protein (APP) cleavage by $\gamma$-secretase and $\beta$-secretase. Dietary supplementation of OL (50 mg/Kg of diet) strongly improved the cognitive performance of young/middle-aged/aged TgCRND8 mice, and it also reduced $\mathrm{B}$-amyloid levels and plaque deposits. Moreover, OL-aglycone-fed mice brain displayed an astonishingly intense autophagy reaction $[175,176,179]$. Similar results were described in transgenic mice (APPswe/PS1dE9), where OL treatment showed significantly reduced amyloid plaque deposition in the cortex and hippocampus as compared to control mice [174]. Moreover, 
OL hindered the amyloid aggregation of $\mathrm{A} \beta$ (1-42) and its cytotoxicity and eliminated the appearance of early toxic oligomers, favoring the formation of stable harmless protofibrils, which were structurally different from the typical A $\beta$ (1-42) fibrils [178]. Using transgenic CL2006 and CL4176 strains of C. elegans strains expressing $A \beta 42$, as a simplified invertebrate model of AD, Diomede et al. evidenced that 50-100 $\mu \mathrm{M}$ OL-fed CL2006 worms displayed reduced A $\beta$ plaque deposition, less abundant toxic $A \beta$ oligomers, remarkably decreased paralysis, and increased lifespan with respect to untreated animals. A protective effect was also observed in CL4176 worms but only when OL was administered before the induction of the $\mathrm{A} \beta$ transgene expression [177] (Table 6).

In vitro studies have revealed that OL prevented the growth of toxic A $\beta 1-42$ oligomers and blocked their successive growth into mature fibrils following its interaction with the peptide N-terminus and attenuated SH-SY5Y cell death caused by A $\beta 42$, copper-A $\beta 42$, and laevodihydroxyphenylalanine (1-DOPA)-A $\beta 42$-induced toxicity after $24 \mathrm{~h}$ treatment, and a marked attenuated $\mathrm{A} \beta$-induced astrocytes and microglia reaction was also found in the nucleus basalis magnocellularis (NBM) from adult male Wistar rats injected with A $\beta 42$ aggregated with OL [171,174,177] (Table 5).

The potential protective effect of OLE in AD has been also investigated in TgSwDI mice. Mice treated for 4 weeks with OLE significantly decreased amyloid load in the hippocampal parenchyma and microvessels. This reduction was associated with enhanced cerebral clearance of $A \beta$ across the blood-brain barrier (BBB), which was accompanied by an increase of P-glycoprotein (P-gp) and low density lipoprotein receptor-related protein 1 (LRP1) expressions, and activated the ApoE-dependent amyloid clearance pathway in the mice brains. The anti-inflammatory effect of OLE in the brains of these mice was also obvious where it was able to reduce astrocytes activation and IL-1 $\beta$ levels [181]. Similarly, $10 \mathrm{mg} / \mathrm{kg}$ of OLE administrated twice daily from 7 to 8 weeks of age and continued for 2 weeks (i.p.) enhanced the clearance of $\mathrm{A} \beta$ from $\mathrm{C} 57 \mathrm{BL} / 6$ wild-type male mice brain and significantly increased the expression of P-gp and LRP1 [182]. In mouse brain endothelial cells (bEnd3), 25 and $50 \mu \mathrm{M}$ OLE treatment resulted in a significant increase in P-gp and LRP1 levels [182]. Moreover, in a 5xFAD mouse model of AD, OLE-rich EVOO consumption, in combination with donepezil, significantly reduced $A \beta$ load and related pathological changes, up-regulated synaptic proteins, enhanced BBB tightness, and reduced neuroinflammation associated with $A \beta$ pathology [180] (Tables 5 and 6).

PD is characterized by a progressive loss of dopaminergic neurons in the midbrain region known as substantia nigra pars compacta and by the presence of cytoplasmic protein aggregates called the Lewy body as well as Lewy neurites in remaining neurons.

Previous studies showed that OL inhibited $\alpha \mathrm{SN}$ amyloidogenesis by directing $\alpha \mathrm{SN}$ monomers into small $\alpha \mathrm{SN}$ oligomers with lower toxicity, thereby suppressing the subsequent fibril growth phase [183]. The neuroprotective effect of OL has been explored in PC12 cells exposed to the potent parkinsonian toxin 6-hydroxydopamine (6-OHDA). OL treatment significantly decreased neuronal death and reduced the mitochondrial production of ROS resulting from blocking superoxide dismutase activity. Moreover, the quantification of autophagy and acidic vesicles in the cytoplasm alongside the expression of specific autophagy markers uncovered a regulatory role for OL against autophagy flux impairment induced by bafilomycin A1 [171,172].

\subsection{Olive Tree Secoiridoids and Ageing}

Aging is a natural biological process that involves the gradual decline of physiological function and the eventual failure of organism homeostasis followed by death. Aging is the process of accumulation of damages to cells, tissues, and organs of an individual that is universal and unique, thereby reducing the overall health of the organism. It is evident that aging can induce stress inside the system in the form of ROS or other stressors, reduce overall health, and induce age-associated neurological diseases [184]. The maintenance of homeostasis between the formation and elimination of damaged proteins is a key process in the development and growth of organisms [185]. To date, very few studies concerning the anti-aging effects of secoiridoids have been performed. However, secoiridoids suggest a potential 
age-related damage regulation based on their antioxidant, anti-inflammatory, and neuroprotector effects (Tables 7 and 8).

Several in vitro studies have supported the potential of OL on the proteasome, which regulates the balance of cellular viability and is crucial in stress, aging, or senescent conditions [185]. The treatment of cell lysates from human embryonic fibroblast IMR90 enhanced three major proteasome catalytic activities: the chymo-trypsin-like (ch-L), the peptidylglutamyl-peptide hydrolase (PGPH) activity, and the trypsin-like (T-L). This activity was supported by Katsiki et al. OL-treated cells retained proteasome function during replicative senescence, and human embryonic fibroblast cultures exhibited a delay appearance of senescence morphology [186]. Santiago-Mora et al. reported the effects of OL on osteoblastogenesis and adipogenesis in mesenchymal stem cells from human bone marrow. OL stimulated osteoclastogenesis rising cellular matrix mineralization and inhibited bone desorption [187] (Table 7).

In terms of epigenetic, it has been postulated that oxidative damage to mitochondrial DNA (mtDNA) is one of several signs of age-related physiological consequences [188]. Fabiani and colleagues reported that OL and OL-algycone form counteracted DNA alterations in HL60 cells and peripheral blood mononuclear cell (PMBC) $\mathrm{H}_{2} \mathrm{O}_{2}$-induced DNA damage [43]. Moreover, $\mathrm{OL}$ counteracted bone loss and reduced $\alpha$-1-acid glycoprotein plasma concentrations in senile osteoporosis rats [189]. Nikou et al. studied the effects of OLE and OLA in Drosophila flies, reporting that dietary administration of both of them was able to increase the T-L proteasome activity and $20 \mathrm{~S}$ and $19 \mathrm{~S}$ proteosomal subunits expression, leading to a significant reduction of ROS levels. Subsequently, it was reported that OLA up-regulated the gene expression of the proteasome, antioxidant response, and molecular chaperones in human skin fibroblasts [190] (Table 8). These data confirmed a potential anti-aging of both secoiridoids and suggested that these compounds could be critical nutraceuticals as preventive and therapeutic treatment of different age diseases. Nevertheless, clinical studies that confirm these suggestions need to be developed in the future.

Table 7. Potential role of secoiridoids obtained from the olive tree in anti-aging: in vitro studies.

\begin{tabular}{|c|c|c|c|c|}
\hline $\begin{array}{l}\text { Phenolic } \\
\text { Compound }\end{array}$ & Cell Line & Concentration & Effects & Reference \\
\hline \multirow{4}{*}{$\mathrm{OLH}_{\mathrm{OL}}$} & Human embryonic fibroblast (IMR90) & {$[0.1-50 \mathrm{mM}]$} & $\begin{array}{l}\text { OL enhanced ch-L, PGPH, and } \\
\text { PGPH proteasome activity }\end{array}$ & [185] \\
\hline & Human embryonic fibroblast & & $\begin{array}{l}\text { OL retained proteasome function } \\
\text { during replicative senescence and } \\
\text { delayed in the appearance of } \\
\text { senescence morphology }\end{array}$ & [186] \\
\hline & $\begin{array}{l}\text { Mesenchymal stem cells from human } \\
\text { bone marrow }\end{array}$ & {$[1-100 \mu \mathrm{M}]$} & $\begin{array}{l}\text { OL enhanced osteogenic gene } \\
\text { expression markers and osteoblast } \\
\text { phenotypic characteristic }\end{array}$ & [187] \\
\hline & $\begin{array}{c}\text { Human promyelocitic leukemia cells } \\
\text { (HL60) }\end{array}$ & $10 \mu \mathrm{M}$ & OL restored DNA damage & [43] \\
\hline \multirow{2}{*}{\multicolumn{5}{|c|}{$\begin{array}{l}\text { Human promyelocitic leukemia cells } \\
\text { (HL60) }\end{array}$}} \\
\hline & & & & \\
\hline OLE & Normal human skin fibroblasts & $\begin{array}{l}50,100,150, \\
\text { and } 200 \mu \mathrm{M}\end{array}$ & $\begin{array}{l}\text { OLE up-regulated genes' } \\
\text { expression of proteasome, } \\
\text { antioxidant responses, and } \\
\text { molecular chaperones genes }\end{array}$ & [190] \\
\hline OLA & Normal human skin fibroblasts & $\begin{array}{l}50,100,150 \\
\text { and } 200 \mu \mathrm{M}\end{array}$ & $\begin{array}{l}\text { OLA up-regulated genes' } \\
\text { expression of proteasome, } \\
\text { antioxidant responses, and } \\
\text { molecular chaperones genes }\end{array}$ & [190] \\
\hline
\end{tabular}


Table 8. Potential role of secoiridoids obtained from the olive tree in anti-aging processes: in vivo studies.

\begin{tabular}{|c|c|c|c|c|}
\hline $\begin{array}{c}\text { Phenolic } \\
\text { Compound }\end{array}$ & Animal Model & Doses & Effects & Reference \\
\hline OL & Senile osteoporosis rats model & $15 \mathrm{mg} / \mathrm{kg}$ & $\begin{array}{l}\text { OL counteracted bone loss and } \\
\text { reduce } \alpha-1 \text {-acid glycoprotein } \\
\text { plasma concentration }\end{array}$ & [189] \\
\hline OLE & Drosophila in vivo model & $\begin{array}{l}\text { Dietary } \\
\text { supplementation of } \\
\text { OLE: } 400 \mathrm{nM}, 200 \mathrm{nM} \text {, } \\
\text { and } 100 \mathrm{nM} \text {. }\end{array}$ & $\begin{array}{l}\text { OLE increased the ch-L } \\
\text { proteasome activity and the } \\
\text { expression of } 20 \mathrm{~S} \text { and } 19 \mathrm{~S} \\
\text { proteasomal subunits and } \\
\text { decreased of ROS levels in } \\
\text { somatic tissues of Drosophila flies }\end{array}$ & [190] \\
\hline OLA & Drosophila in vivo model & $\begin{array}{c}\text { Dietary } \\
\text { supplementation of } \\
\text { OLA: } 400 \mathrm{nM}, 200 \mathrm{nM} \text {, } \\
\text { and } 100 \mathrm{nM}\end{array}$ & $\begin{array}{l}\text { OLA increased the ch-L } \\
\text { proteasome activity and the } \\
\text { expression of } 20 \mathrm{~S} \text { and } 19 \mathrm{~S} \\
\text { proteasomal subunits and } \\
\text { decreased of ROS levels in } \\
\text { somatic tissues of Drosophila flies. }\end{array}$ & [190] \\
\hline
\end{tabular}

\subsection{Secoiridoids Olive Tree in Autoimmune Diseases}

Autoimmune diseases are heterogeneous groups of diseases whose condition is that your immune system mistakenly attacks your body. In the normal state, the immune system is able to differentiate between foreign cells, such as viruses and bacteria, and its own cells. However, in an autoimmune disease, the immune system recognizes our own cells as foreign cells and it releases proteins called autoantibodies that attack healthy cells. These types of diseases could appear at any stage of life with higher or lower severity. For example, there are types of autoimmune disease that target only one organ, such as type 1 diabetes mellitus (T1DM), which damages the pancreas, whereas there are other diseases, such as systemic lupus erythematosus (SLE), which affect the whole body.

The National Institutes of Health (NIH) estimates that up to 23.5 million Americans suffer from autoimmune disease and that the prevalence rose in 2019. For this reason, autoimmune diseases are recognized as a major health problem. Nowadays, researchers have identified 80-100 different autoimmune diseases and suspect at least 40 more diseases of having an autoimmune basis. These diseases are chronic, can be life-threatening, and are responsible for death in female children and women in all age groups up to 64 years old [191]. The most characteristic examples of these kinds of autoimmune diseases are rheumatoid arthritis (RA), SLE, Crohn's disease, ulcerative colitis (UC), and T1DM.

RA can be defined as a chronic inflammatory disease with a systemic autoimmune component, and it is mainly characterized by aggressive synovial hyperplasia, synovitis, the progressive destruction of cartilage, and bone erosion with the painful swelling of small joints, fatigue, prolonged stiffness and fever caused by immune responses, and specific innate inflammatory processes [192]. Worldwide, the annual incidence of RA is approximately three cases per 10,000 people, and the prevalence rate is approximately $1 \%$ increasing with age and peaking between the ages of 35 and 50 years old. RA affects all populations, although it is much more prevalent in some groups (e.g., 5-6\% in some Native American groups) and much less prevalent in others (e.g., black persons from the Caribbean region) [193].

SLE can be defined as a chronic inflammatory and autoimmune disease that can affect multiple organ systems, including skin, joints, kidneys, and the brain, among others [194]. SLE is characterized by a deposition of immune complexes, which are formed in large amounts as antinuclear antibodies bind to the abundant nuclear material in blood and tissues, along with disturbances in both innate and adaptive immunity and T-cell signaling. In addition, SLE is characterized by its clinical and pathogenic complexity, difficult diagnosis, and the high number of complications that can affect the patient's quality of life [195]. There are worldwide differences in the incidence and prevalence of SLE that vary with sex, age, ethnicity, and time. The highest estimates of incidence and prevalence of SLE were in North America: 23.2/10000 persons/years and 24/10000, people respectively. The lowest incidences 
of SLE were reported in Africa and the Ukraine (0.3/10000 persons/years), and the lowest prevalence was observed in Northern Australia ( 0 cases in sample of 847 people). Women were more frequently affected than men for every age and ethnic group. Incidence peaked in middle adulthood and occurred later for men. People of black ethnicity had the highest incidence and prevalence of SLE, whereas those with white ethnicity had the lowest incidence and prevalence. This appeared to be an increasing trend of SLE prevalence with time [196].

Crohn's disease and UC are important chronic inflammatory disorders of the gastrointestinal system that contribute to the inflammatory bowel conditions, such as diarrhea with or without blood, abdominal pain, fever, weight loss, inflammation, and ulcers. These diseases have uncertain etiology but can be associated with multifactorial conditions in terms of immunity, genetics, and non-immune conditions such as environmental factors [197]. The total number of new cases of Crohn's disease diagnosed each year (incidence) was 10.7 per 100,000 people or approximately 33,000 new cases per year. The total number of new cases of UC diagnosed each year was 12.2 per 100,000 people or approximately 38,000 new cases per year [198].

T1DM is considered an autoimmune disease that results from the destruction of pancreatic $\beta$-cells and is mediated by the immune system. This is caused by an autoimmune reaction where the body's defense system attacks the cells that produce insulin. As a result, the body produces very little or no insulin. Multiple genetic and environmental factors found in variable combinations in individual patients are involved in the development of T1DM. Genetic risk is defined by the presence of particular allele combinations, which in the major susceptibility locus (the HLA region) affect T-cell recognition and tolerance to foreign and autologous molecules. T1DM can affect people at any age, but it usually develops in children or young adults. Around 10\% of all people with diabetes have T1DM [199].

Due to the high prevalence and rising incidence of this kind of disease, nowadays, there is a requirement to investigate to develop palliative remedies or treatments that help us improve the symptoms and management of these types of diseases to improve the quality of life of patients. A new source of news alternative for autoimmune diseases is based on the use of natural compounds obtained from natural resources, such as Olea europaea L., which is traditionally used as diuretic, hypotensive, emollient, laxative, febrifuge, skin cleanser, and it is also used for the treatment of urinary infections, gallstones, bronchial asthma, and diarrhea. The published studies related to the effects of secoiridoids from the olive tree in these autoimmune diseases are summarized in Tables 9 and 10.

Table 9. Effective mechanisms and concentrations of bioactive secoiridoids from the olive tree in in vitro models of immunoinflammatory diseases.

\begin{tabular}{|c|c|c|c|c|}
\hline $\begin{array}{l}\text { Phenolic } \\
\text { Compound }\end{array}$ & Cell Line & Concentration & Effects & Reference \\
\hline & $\begin{array}{l}\text { LPS-stimulated murine peritoneal } \\
\text { macrophages. }\end{array}$ & 25 and $50 \mu \mathrm{M}$ & $\begin{array}{l}\text { OL reduced pro-inflammatory } \\
\text { cytokines levels and interferon } \\
\text { (IFN)- } \gamma \text {, as well as iNOS and } \\
\text { COX-2 overexpressions }\end{array}$ & [200] \\
\hline OL & $\begin{array}{l}\text { Human synovial fibroblasts cell line } \\
\text { (SW982) }\end{array}$ & 50 and $100 \mu \mathrm{M}$ & $\begin{array}{l}\text { OL pre-treatment down-regulated } \\
\text { mitogen active protein kinase } \\
\text { (MAPK)s and NF-kB and } \\
\text { induction of Nrf2-linked HO-1 } \\
\text { signaling pathways }\end{array}$ & [201] \\
\hline OLE & $\begin{array}{l}\text { LPS-stimulated murine peritoneal } \\
\text { macrophages. }\end{array}$ & {$[25-100 \mu \mathrm{M}]$} & $\begin{array}{l}\text { OLE showed a potent reduction of } \\
\text { ROS, nitrites, and } \\
\text { pro-inflammatory cytokines levels. } \\
\text { OLE inhibited canonical and } \\
\text { noncanonical inflammasome } \\
\text { signaling pathways }\end{array}$ & [50] \\
\hline
\end{tabular}


Table 10. Effective mechanisms and concentrations of bioactive secoiridoids from the olive tree in in vivo models and clinical trials of immunoinflammatory diseases.

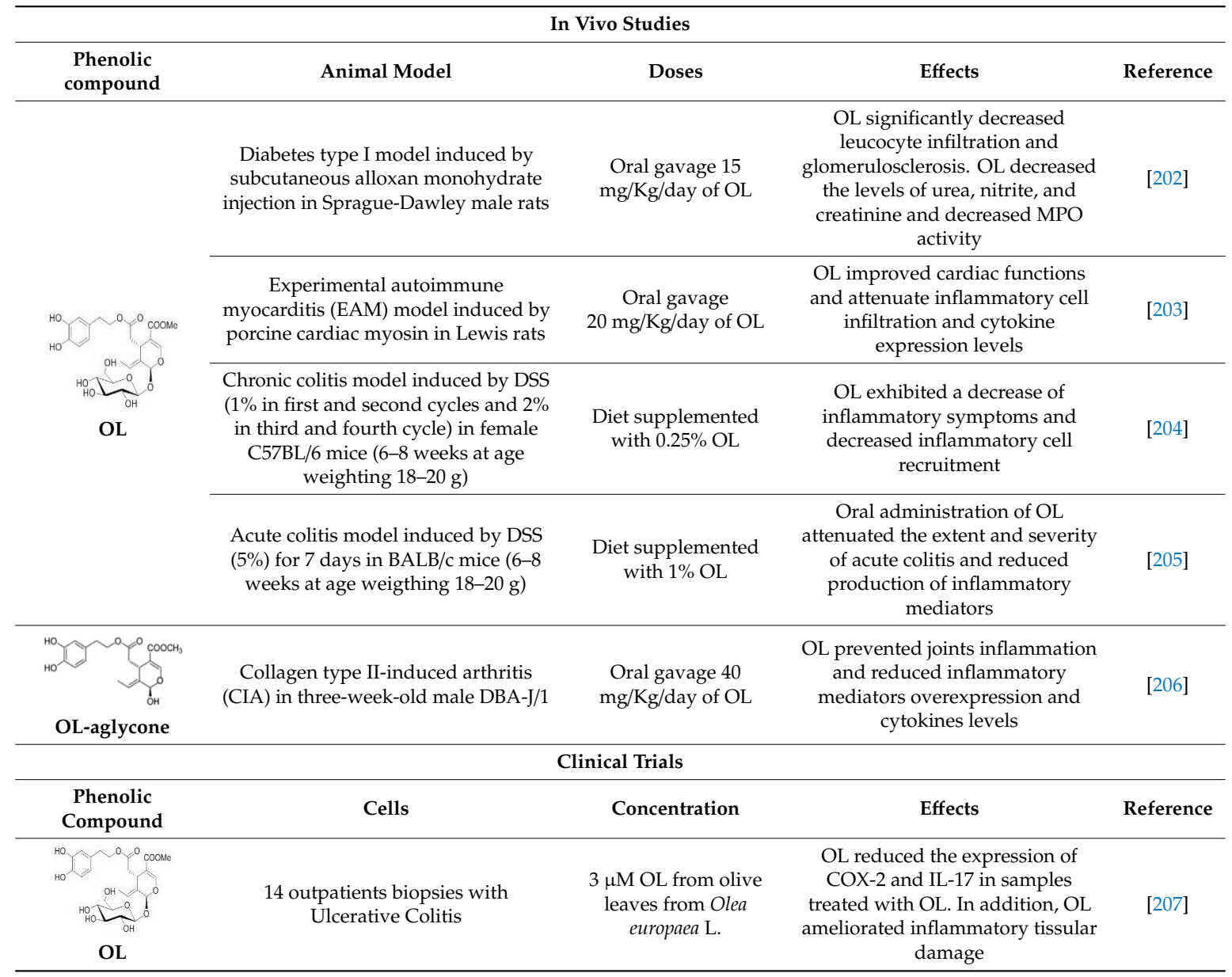

\section{Conclusions}

There is evidence indicating that secoiridoids from the olive tree has a large potential as a therapy for a wide variety of ROS-related diseases. Interesting studies performed with animal and cell models suggest that secoiridods intake may be beneficial for the prevention and adjuvant treatment of such diseases. Particularly, dietary supplementation of OL, OL-aglycone, or OLE strongly improved the cognitive performance as well as reduced $\beta$-amyloid levels and plaque deposits favoring the formation of stable harmless protofibrils in transgenic mice models of AD. Likewise, using transgenic strains of $C$. elegans, OL-fed CL2006 worms displayed reduced A $\beta$ plaque deposition, less abundant toxic $\mathrm{A} \beta$ oligomers, remarkably decreased paralysis, and increased lifespan. Besides, OL prevented the growth of toxic A $\beta 1-42$ oligomers and cell death in SH-SY5Y cells, increased P-gp and LRP1 levels in mouse brain endothelial cells, and a marked attenuated $\mathrm{A} \beta$-induced astrocytes and microglia reaction was also described in the NBM of adult male Wistar rats injected with A $\beta 42$ aggregated with OL. The neuroprotective effect of OL secoiridoid has been slightly explored in PD. OL treatment has been demonstrated to inhibit $\alpha \mathrm{SN}$ amyloidogenesis, suppressing the subsequent fibril growth phase, decreasing neuronal death, and reducing the mitochondrial production of ROS resulting from blocking superoxide dismutase activity in PC12 cells exposed to 6-OHDA.

The best-documented cardiovascular protector secoiridoid is OL. The literature reviewed here validates that the treatment of cells and animal models with OL could be beneficial in combating oxidative stress and thereby protect individuals from cardiovascular diseases. The beneficial effects of secoiridoids have been attributed to their antioxidant capacity and their ability to modulate cellular antioxidant defense mechanisms. In addition, OL has been shown to modulate a variety of targets, 
which include iNOS and NO, TNF $\alpha$, IL-8 and MMP-2 and MMP-9 in addition to VCAM-1 and ICAM-1, and modulating signaling pathways by altering MAPK, NFkB, and Nrf2/HO-1, among others. Finally, secoiridoid supplemented diets exerted a reduction in infarct size, total cholesterol, and triglyceride concentrations. On the contrary, the cardiovascular protection effects of OLE and OLA as well as clinical trials of the effects of these secoiridoids on cardiovascular diseases are very scant, and future studies are needed to confirm them in cardiovascular disorders.

OL has also shown considerable anti-cancer effects against many types of cancer, including breast cancer, colorectal cancer, prostate cancer, pancreatic cancer, cervical carcinoma, and thyroid cancer both in vitro and in vivo. OL is believed to exert its anticancer activity via multiple mechanisms, interfering with different cellular pathways and inducing/inhibiting the production of various types of cytokines, enzymes, or growth factors such as MAPKs, NF-kB, Akt, COX-2, and STAT3. On the contrary, the studies reporting the anti-cancer effects of OLE and OLA are very circumscribed to breast cancer, hepatocellular carcinoma, and hematologic neoplasias.

On the other hand, the remarkable anti-inflammatory and immunomodulatory effects of these bioactive compounds have been reported in several in vitro and experimental models of RA, SLE, inflammatory bowel disease (IBD), T1DM, and multiple sclerosis (MS). Particularly, OL, OLA, and OLE may exert a remarkable inmmunodulatory and anti-inflammatory effects reducing the induced inflammatory response in murine macrophages and human fibroblasts. This was accompanied by amelioration of the production of essential pro-inflammatory cytokines involved in the regulation of the immune system response through the prevention of MAPKs and NF-KB pathways activation. Moreover, OL and OLA secoiridoids were effective in preventing the induced immuno-inflammatory response in animal experimental models of UC, MS, T1DM, and SLE. Finally, very few studies about secoiridoids' anti-aging effects have been performed to date. Nevertheless, secoiridoids suggest posing a potential age-related damage regulation based on their antioxidant, anti-inflammatory, and neuroprotector effects.

In conclusion, the published data revealed, in general, consistent and very satisfactory results; however, the knowledge is very limited, especially in clinical trials. In this sense, further efforts are needed to mechanistically clarify the underlying biochemical and biological activities and pharmacokinetics/pharmacodynamics of secoiridoids from the olive tree in additional preclinical and clinical studies of ROS-related diseases.

Author Contributions: M.S.-H. and C.A.-d.-1.-L. conceived the idea. M.L.C., T.M., M.S.-H., and C.A.-d.-1.-L. performed the review of papers. M.S.-H., L.C., and T.M. wrote the first draft of the manuscript. All authors made meaningful contributions to the final manuscript and approved the manuscript for final submission. All authors have read and agreed to the published version of the manuscript.

Funding: The authors gratefully acknowledge the financial support by a research grant (Reference: AG2017-89342-P) from the Ministerio de Economía y Competitividad of Spain.

Conflicts of Interest: The authors declare no conflict of interest.

$\begin{array}{ll}\text { Abbreviations } & \\ \text { 3:4-DHPEA-EDA } & \text { 3,4-(dihidrophenyl)etanol } \\ \text { 3-MA } & \text { 3-methyladenine } \\ \text { 6-OHDA } & \text { 6-hydroxydopamine } \\ \text { 8-OH-dG } & \text { 8-hydroxy-2'deoxy-guanosine } \\ \text { AD } & \text { Alzheimer's disases } \\ \text { AGE } & \text { advanced glycoxidation products } \\ \text { Akt } & \text { Protein kinase B } \\ \text { ALE } & \text { Advanced lipid peroxidation products } \\ \text { APP } & \text { Amyloid precursor protein } \\ \text { ASM } & \text { acid sphingomyelinase } \\ \text { AUC } & \text { area under the curve }\end{array}$




\begin{tabular}{|c|c|}
\hline BBB & Blood-brain barrier \\
\hline BMI & Body mass index \\
\hline BMSC & Bone marrow stromal cells \\
\hline BTG3 & B-cell translocation gene 3 \\
\hline ch-L & Chymo-trypsin-like \\
\hline CIA & Collagen-induced arthritis \\
\hline c-MET & Tyrosine-protein kinase Met \\
\hline $\operatorname{cox}$ & Cyclooxigenase \\
\hline CPK & Creatine phosphokinase \\
\hline CRC & Colorrectal cancer \\
\hline DSS & Dextran sulfate sodium \\
\hline EAM & Experimental autoimmune myocarditis \\
\hline $\mathrm{EC}$ & Esophagical cancer \\
\hline ER & Estrogen receptor \\
\hline ERK & Extracellular signal-regulated kinases \\
\hline EVOO & Extra virgin olive oil \\
\hline GES & Geraniol synthase \\
\hline GPER & G-protein coupled receptor \\
\hline GPx & Glutathione peroxidase \\
\hline GT & Glucosyltransferase \\
\hline $\mathrm{h}$ & hours \\
\hline $\mathrm{HCC}$ & Hepatocellular carcinoma \\
\hline HDAC & Histone deacetylase \\
\hline HDL & High-density lipoprotein \\
\hline HFD & High fat diet \\
\hline HGF & Hepatocyte growth factor \\
\hline HIF-1 $\alpha$ & Hypoxia-inducible factor $1 \alpha$ \\
\hline $\mathrm{HO}-1$ & Heme oxigenase- 1 \\
\hline HTy & Hydroxytyrosol \\
\hline IBD & Inflammatory bowel disease \\
\hline ICAM-1 & Intracellular adhesión molecule-1 \\
\hline IL & Interleukin \\
\hline iNOS & Inducible nitric oxide synthase \\
\hline i.p. & intraperitoneally \\
\hline JNK & c-Jun N-terminal kinase \\
\hline LDL & Low-density lioprotein \\
\hline LMP & Lyposomal membrane permeabilization \\
\hline LP & Lapatinib \\
\hline LRP1 & Lipoprotein receptor-related protein 1 \\
\hline MAO-A & Monoamine oxidase-A \\
\hline MDA & Malodialdehyde \\
\hline $\min$ & minutes \\
\hline MIP- $\alpha$ & Macrophage inflammatory $1 \alpha$ \\
\hline MM & Multiple mieloma \\
\hline MMPs & Metalloproteinases \\
\hline $\mathrm{MPO}$ & Myeloperoxidase \\
\hline MS & Multiple sclerosis \\
\hline mtDNA & mitochondrial DNA \\
\hline mTOR & mammalian target of rapamycin \\
\hline $\mathrm{NADH}$ & Nicotinamide adenine dinucleotide reduced form \\
\hline NBM & Nucleus basalis magnocellularis \\
\hline NEP & Neutral endopeptidase \\
\hline NFTs & Neurofibrillary tangles \\
\hline
\end{tabular}




$\begin{array}{ll}\text { NF-kB } & \text { Nuclear transcription factor-kappa B } \\ \text { NGB } & \text { Pro-nerve growth factor } \\ \text { NIH } & \text { National institute of Health } \\ \text { NO } & \text { Nitric oxide } \\ \text { NOX } & \text { NADPH oxidase } \\ \text { NPC } & \text { Nasopharingeal carcinoma } \\ \text { Nrf2 } & \text { Nuclear factor E2-related factor 2 } \\ \text { NSCLC } & \text { Non-small cell lung cáncer } \\ \text { OL } & \text { Oleuropein } \\ \text { OLA } & \text { Olacein } \\ \text { OLE } & \text { Oleocanthal } \\ \text { OS } & \text { Osteosarcoma } \\ \text { PD } & \text { Parkinson's disease } \\ \text { P-gp } & \text { P-glycoprotein } \\ \text { PGPH } & \text { Peptidylgutamyl-peptide hydrolase } \\ \text { PI3K } & \text { Phosphatidylinositol 3-kinase } \\ \text { PBMC } & \text { Peripheral blood mnonuclear cells } \\ \text { PTB1B } & \text { Protein tyrosine phosphatase 1B } \\ \text { RA } & \text { Rheumatoid arthritis } \\ \text { ROS } & \text { Reactive oxygen species } \\ \text { SBP } & \text { Systolic blood pressure } \\ \text { SLS } & \text { Secologanin synthase } \\ \text { SPAK } & \text { Ste20-like proline alanine rich kinase } \\ \text { SLE } & \text { Systemic lupus erythematosus } \\ \text { STAT } & \text { Signal transducer and activator of transcription } \\ \text { T1DM } & \text { Type 1 Diabetes mellitus } \\ \text { TIMPs } & \text { Tissue inhibitors of metalloproteinases } \\ \text { T-L } & \text { Trypsin-like } \\ \text { Ty } & \text { Tyrosol } \\ \text { UC } & \text { Ulcerative colitis } \\ \text { VCAM-1 } & \text { Vascular cell adhesión molecule-1 } \\ \text { VEGF } & \text { Vascular endotelial growth factor } \\ & \end{array}$

\section{References}

1. Boros, C.A.; Stermitz, F.R. Iridoids. updated part. J. Nat. Prod. 1990, 53, 1055-1147. [CrossRef]

2. El-Naggar, L.J.; Beal, J.L. Iridoids: A Review. J. Nat. Prod. 1980, 43, 649-707. [CrossRef] [PubMed]

3. Dinda, B.; Debnath, S.; Harigaya, Y. Naturally Occurring Secoiridoids and Bioactivity of Naturally Occurring Iridoids and Secoiridoids: A Review, Part 2. Chem. Pharm. Bull. (Tokyo) 2007, 55, 689-728. [CrossRef] [PubMed]

4. Hegnauer, R.; Kooiman, P. The Taxonomic Significance of Iridoids of Tubiflorae Sensu Wettstein (Author's Transl). Planta Med. 1978, 33, 1-33. [CrossRef] [PubMed]

5. Sticher, O.V.; Junod-Busch, U. The Iridoid Glucoside and Its Isolation. Pharm. Acta Helvetiae 1975, 50, $127-144$.

6. Huang, Y.-L.; Oppong, M.B.; Guo, Y.; Wang, L.-Z.; Fang, S.-M.; Deng, Y.-R.; Gao, X.-M. The Oleaceae Family: A Source of Secoiridoids with Multiple Biological Activities. Fitoter 2019, 136, 104155. [CrossRef]

7. Ghanbari, R.; Anwar, F.; Alkharfy, K.M.; Gilani, A.-H.; Saari, N. Valuable Nutrients and Functional Bioactives in Different Parts of Olive (Olea europaea L.) —A Review. Int. J. Mol. Sci. 2012, 13, 3291-3340. [CrossRef]

8. Somova, L.; Shode, F.; Ramnanan, P.; Nadar, A. Antihypertensive, Antiatherosclerotic and Antioxidant Activity of Triterpenoids Isolated from Olea Europaea, Subspecies Africana Leaves. J. Ethnopharmacol. 2003, 84, 299-305. [CrossRef]

9. Sheth, A.; Mitaliya, K.D.; Joshi, S. The herbs of Ayurveda, 1st ed.; Ashok Sheth: Gujarat, India, 2005.

10. Bellakhdar, J.; Claisse, R.; Fleurentin, J.; Younos, C. Repertory of Standard Herbal Drugs in the Moroccan Pharmacopoea. J. Ethnopharmacol. 1991, 35, 123-143. [CrossRef] 
11. Alarcon-Aguilara, F.J.; Roman-Ramos, R.; Perez-Gutierrez, S.; Aguilar-Contreras, A.; Contreras-Weber, C.C.; Flores-Saenz, J.L. Study of the Anti-Hyperglycemic Effect of Plants Used as Antidiabetics. J. Ethnopharmacol. 1998, 61, 101-110. [CrossRef]

12. Ribeiro, R.D.A.; De Melo, M.R.; De Barros, F.; Gomes, C.; Trolin, G. Acute Antihypertensive Effect in Conscious Rats Produced by Some Medicinal Plants Used in the State of São Paulo. J. Ethnopharmacol. 1986, 15, 261-269. [CrossRef]

13. Pieroni, A.; Heimler, D.; Pieters, L.; Van Poel, B.; Vlietinck, A.J. In Vitro Anti-Complementary Activity of Flavonoids from Olive (Olea europaea L.) Leaves. Die Pharm. 1996, 51, 765-768.

14. De Feo, V.; Aquino, R.; Menghini, A.; Ramundo, E.; Senatore, F. Traditional Phytotherapy in the Peninsula Sorrentina, Campania, Southern Italy. J. Ethnopharmacol. 1992, 36, 113-125. [CrossRef]

15. Ghazanfar, S.A.; Al-Al-Sabahi, A.M. Medicinal Plants of Northern and Central Oman (Arabia). Econ. Bot. 1993, 47, 89-98. [CrossRef]

16. Termentzi, A.; Halabalaki, M.; Skaltsounis, A.L. From Drupes to Olive Oil: An Exploration of Olive Key Metabolites. In Olive and Olive Oil Bioactive Constituents; Boskou, D., Ed.; Elsevier: Amsterdam, Netherlands, 2015; pp. 147-177.

17. Perez-Martinez, P.; López-Miranda, J.; Blanco-Colio, L.; Bellido, C.; Jimenez, Y.; Moreno, J.A.; Delgado-Lista, J.; Egido, J.; Pérez-Jiménez, F. The Chronic Intake of a Mediterranean Diet Enriched in Virgin Olive Oil, Decreases Nuclear Transcription Factor kB Activation in Peripheral Blood Mononuclear Cells from Healthy Men. Atherosclerosis 2007, 194, e141-e146. [CrossRef]

18. Jensen, S. Chemotaxonomy of the Oleaceae: Iridoids as Taxonomic Markers. Phytochemistry 2002, 60, $213-231$. [CrossRef]

19. Obied, H.K.; Prenzler, P.D.; Ryan, D.; Servili, M.; Taticchi, A.; Esposto, S.; Robards, K. Biosynthesis and Biotransformations of Phenol-Conjugated Oleosidic Secoiridoids from Olea europaea L. Nat. Prod. Rep. 2008, 25, 1167. [CrossRef]

20. Maestri, D.; Barrionuevo, D.; Bodoira, R.; Zafra, A.; Jiménez-López, J.; Alché, J.D.D. Nutritional Profile and Nutraceutical Components of Olive (Olea europaea L.) Seeds. J. Food Sci. Technol. 2019, 56, 4359-4370. [CrossRef]

21. Kanakis, P.; Termentzi, A.; Michel, T.; Gikas, E.; Halabalaki, M.; Skaltsounis, A.-L. From Olive Drupes to Olive Oil: An HPLC-Orbitrap-based Qualitative and Quantitative Exploration of Olive Key Metabolites. Planta Med. 2013, 79, 1576-1587. [CrossRef] [PubMed]

22. Gómez-Rico, A.; Inarejos-García, A.M.; Salvador, M.D.; Fregapane, G. Effect of Malaxation Conditions on Phenol and Volatile Profiles in Olive Paste and the Corresponding Virgin Olive Oils (Olea europaea L. Cv. Cornicabra). J. Agric. Food Chem. 2009, 57, 3587-3595. [CrossRef]

23. Caruso, D.; Colombo, R.; Patelli, R.; Giavarini, F.; Galli, G. Rapid Evaluation of Phenolic Component Profile and Analysis of Oleuropein Aglycon in Olive Oil by Atmospheric Pressure Chemical Ionization-Mass Spectrometry (APCI-MS). J. Agric. Food Chem. 2000, 48, 1182-1185. [CrossRef] [PubMed]

24. Obied, H.K.; Bedgood, D.R.; Prenzler, P.D.; Robards, K.D.R.B., Jr. Chemical Screening of Olive Biophenol Extracts by Hyphenated Liquid Chromatography. Anal. Chim. Acta 2007, 603, 176-189. [CrossRef] [PubMed]

25. Gutierrez-Rosales, F.; Romero, M.P.; Casanovas, M.; Motilva, M.J.; Mínguez-Mosquera, M.I. Metabolites Involved in Oleuropein Accumulation and Degradation in Fruits of Olea europaea L.: Hojiblanca and Arbequina Varieties. J. Agric. Food Chem. 2010, 58, 12924-12933. [CrossRef] [PubMed]

26. Ryan, D.; Antolovich, M.; Herlt, T.; Prenzler, P.D.; Lavee, S.; Robards, K. Identification of Phenolic Compounds in Tissues of the Novel Olive Cultivar Hardy's Mammoth. J. Agric. Food Chem. 2002, 50, 6716-6724. [CrossRef]

27. Ryan, D.; Prenzler, P.D.; Lavee, S.; Antolovich, M. and Robards, K. Quantitative Changes in Phenolic Content during Physiological Development of the Olive (Olea europaea) Cultivar Hardy's Mammoth. J. Agric. Food Chem. 2003, 51, 2532-2538. [CrossRef]

28. Savarese, M.; Demarco, E.; Sacchi, R. Characterization of Phenolic Extracts from Olives (Olea europaea cv. Pisciottana) by Electrospray Ionization Mass Spectrometry. Food Chem. 2007, 105, 761-770. [CrossRef]

29. Servili, M.; Baldioli, M.; Selvaggini, R.; Miniati, E.; Macchioni, A.; Montedoro, G. High-Performance Liquid Chromatography Evaluation of Phenols in Olive Fruit, Virgin Olive Oil, Vegetation Waters, and Pomace and 1D- and 2D-Nuclear Magnetic Resonance Characterization. J. Am. Oil Chem. Soc. 1999, 76, 873-882. [CrossRef] 
30. Presti, G.; Guarrasi, V.; Gulotta, E.; Provenzano, F.; Provenzano, A.; Giuliano, S.; Monfreda, M.; Mangione, M.; Passantino, R.; Biagio, P.S.; et al. Bioactive Compounds from Extra Virgin Olive Oils: Correlation between Phenolic Content and Oxidative Stress Cell Protection. Biophys. Chem. 2017, 230, 109-116. [CrossRef]

31. Cárdeno, A.; Sánchez-Hidalgo, M.; Alarcón-De-La-Lastra, C. An Up-Date of Olive Oil Phenols in Inflammation and Cancer: Molecular Mechanisms and Clinical Implications. Curr. Med. Chem. 2013, 20, 4758-4776. [CrossRef]

32. Czerwińska, M.; Kiss, A.K.; Naruszewicz, M. A Comparison of Antioxidant Activities of Oleuropein and Its Dialdehydic Derivative from Olive Oil, Oleacein. Food Chem. 2012, 131, 940-947. [CrossRef]

33. Paiva-Martins, F.; Fernandes, J.; Santos, V.; Silva, L.; Borges, F.; Rocha, S.; Belo, L.; Santos-Silva, A. Powerful Protective Role of 3,4-dihydroxyphenylethanol-elenolic acid Dialdehyde against Erythrocyte Oxidative-Induced Hemolysis. J. Agric. Food Chem. 2010, 58, 135-140. [CrossRef] [PubMed]

34. De La Lastra, C.A.; Villegas, I. Resveratrol as an Antioxidant and Pro-Oxidant Agent: Mechanisms and Clinical Implications. Biochem. Soc. Trans. 2007, 35, 1156-1160. [CrossRef] [PubMed]

35. Rosignoli, P.; Fuccelli, R.; Fabiani, R.; Servili, M.; Morozzi, G. Effect of Olive Oil Phenols on the Production of Inflammatory Mediators in Freshly Isolated Human Monocytes. J. Nutr. Biochem. 2013, 24, 1513-1519. [CrossRef] [PubMed]

36. Kaeidi, A.; Sahamsizadeh, A.; Allahtavakoli, M.; Fatemi, I.; Rahmani, M.; Hakimizadeh, E.; Hassanshahi, J. The Effect of Oleuropein on Unilateral Ureteral Obstruction Induced-Kidney Injury in Rats: The Role of Oxidative Stress, Inflammation and Apoptosis. Mol. Biol. Rep. 2020, 47, 1371-1379. [CrossRef] [PubMed]

37. Tavafi, M.; Ahmadvand, H.; Toolabi, P. Inhibitory Effect of Olive Leaf Extract on Gentamicin-Induced Nephrotoxicity in Rats-Yafteh. Iran. J. Kidney Dis. 2012, 6, 25-32.

38. Beiranvand, A.; Rasoulian, B.; Alizerai, M.; Hashemi, P.; Pilevarian, A.A.; Ezatpor, B.; Tavafi, M.; Chash, S. Pretreatment with Olive Leaf Extract Partially Attenuates Cisplatin-Induced Nephrotoxicity in Rats-Yafteh. Available online: http://yafte.lums.ac.ir/browse.php?a_id=190\&sid=1\&slc_lang=en (accessed on 15 January 2020).

39. Dias, M.C.; Pinto, D.C.G.A.; Freitas, H.; Santos, C.; Silva, A.M.S. The Antioxidant System in Olea Europaea to Enhanced UV-B Radiation also depends on Flavonoids and Secoiridoids. Phytochemistry 2020, 170, 112199. [CrossRef]

40. Bars-Cortina, D.; Hazas, M.-C.L.D.L.; Benavent-Vallés, A.; Motilva, M.-J. Impact of Dietary Supplementation with Olive and Thyme Phenols on alpha-tocopherol Concentration in the Muscle and Liver of Adult Wistar Rats. Food Funct. 2018, 9, 1433-1443. [CrossRef]

41. Gouvinhas, I.; Machado, N.; Sobreira, C.; Domínguez-Perles, R.; Gomes, S.; Rosa, E.; Barros, A.; Gouvinhas, I.; Machado, N.; Sobreira, C.; et al. Critical Review on the Significance of Olive Phytochemicals in Plant Physiology and Human Health. Molecules 2017, 22, 1986. [CrossRef]

42. Visioli, F.; Bellomo, G.; Galli, C. Free Radical-Scavenging Properties of Olive Oil Polyphenols. Biochem. Biophys. Res. Commun. 1998, 247, 60-64. [CrossRef]

43. Fabiani, R.; Rosignoli, P.; De Bartolomeo, A.; Fuccelli, R.; Servili, M.; Montedoro, G.F.; Morozzi, G. Oxidative DNA Damage Is Prevented by Extracts of Olive Oil, Hydroxytyrosol, and Other Olive Phenolic Compounds in Human Blood Mononuclear Cells and HL60 Cells. J. Nutr. 2008, 138, 1411-1416. [CrossRef] [PubMed]

44. Hussain, T.; Tan, B.; Yin, Y.; Blachier, F.; Tossou, M.C.B.; Rahu, N. Oxidative Stress and Inflammation: What Polyphenols Can Do for Us? Oxid. Med. Cell. Longev. 2016, 2016. [CrossRef] [PubMed]

45. Benavente-García, O.; Castillo, J.; Lorente, J.; Ortuño, A.; Del Rio, J. Antioxidant Activity of Phenolics Extracted from Olea europaea L. leaves. Food Chem. 2000, 68, 457-462. [CrossRef]

46. Sarica, S.; Toptas, S. Effects of Dietary Oleuropein Supplementation on Growth Performance, Serum Lipid Concentrations and Lipid Oxidation of Japanese Quails. J. Anim. Physiol. Anim. Nutr. 2014, 98, 1176-1186. [CrossRef] [PubMed]

47. De La Ossa, J.G.; Felice, F.; Azimi, B.; Salsano, J.E.; Digiacomo, M.; Macchia, M.; Danti, S.; Di Stefano, R. Waste Autochthonous Tuscan Olive Leaves (Olea europaea var. Olivastra seggianese) as Antioxidant Source for Biomedicine. Int. J. Mol. Sci. 2019, 20, 5918. [CrossRef] [PubMed]

48. Tripoli, E.; Giammanco, M.; Tabacchi, G.; Di Majo, D.; Giammanco, S.; La Guardia, M. The Phenolic Compounds of Olive Oil: Structure, Biological Activity and Beneficial Effects on Human Health. Nutr. Res. Rev. 2005, 18, 98-112. [CrossRef] [PubMed] 
49. Visioli, F.; Galli, C. Oleuropein Protects Low Density Lipoprotein from Oxidation. Life Sci. 1994, 55, $1965-1971$. [CrossRef]

50. Montoya, T.; Castejón, M.L.; Sánchez-Hidalgo, M.; González-Benjumea, A.; Fernández-Bolaños, J.G.; De-La-Lastra, C.A. Oleocanthal Modulates LPS-Induced Murine Peritoneal Macrophages Activation via Regulation of Inflammasome, Nrf-2/HO-1, and MAPKs Signaling Pathways. J. Agric. Food Chem. 2019, 67, 5552-5559. [CrossRef]

51. Soler-Rivas, C.; Marín, F.R.; Santoyo, S.; García-Risco, M.R.; Señoráns, F.J.; Reglero, G. Testing and Enhancing the in vitro Bioaccessibility and Bioavailability of Rosmarinus Officinalis Extracts with a High Level of Antioxidant Abietanes. J. Agric. Food Chem. 2010, 58, 1144-1152. [CrossRef]

52. Vissers, M.N.; Zock, P.L.; Roodenburg, A.J.C.; Leenen, R.; Katan, M.B. Olive Oil Phenols Are Absorbed in Humans. J. Nutr. 2002, 132, 409-417. [CrossRef]

53. Imran, M.; Nadeem, M.; Gilani, S.A.; Khan, S.; Sajid, M.W.; Amir, R.M. Antitumor Perspectives of Oleuropein and Its Metabolite Hydroxytyrosol: Recent Updates. J. Food Sci. 2018, 83, 1781-1791. [CrossRef]

54. Francisco, V.; Ruiz-Fernandez, C.; Lahera, V.; Lago, F.; Pino, J.; Skaltsounis, L.; González-Gay, M.A.; Mobasheri, A.; Gomez, R.; Scotece, M.; et al. Natural Molecules for Healthy Lifestyles: Oleocanthal from Extra Virgin Olive Oil. J. Agric. Food Chem. 2019, 67, 3845-3853. [CrossRef] [PubMed]

55. D'Archivio, M.; Filesi, C.; Varì, R.; Scazzocchio, B.; Masella, R. Bioavailability of the Polyphenols: Status and Controversies. Int. J. Mol. Sci. 2010, 11, 1321-1342. [CrossRef]

56. Kendall, M.; Batterham, M.; Callahan, D.L.; Jardine, D.; Prenzler, P.D.; Robards, K.; Ryan, D.; Kendall, M.; Batterham, M.; Callahan, D.L.; et al. Title: Randomized Controlled Study of the Urinary Excretion of Biophenols Following Acute and Chronic Intake of Olive Leaf Supplements. Food Chem. 2012, 130, 651-659. [CrossRef]

57. Karkovíc, A.K.; Markovíc, M.; Toríc, J.T.; Barbaríc, M.B.; Jakobušíc, C.; Brala, J. Molecules Hydroxytyrosol, Tyrosol and Derivatives and Their Potential Effects on Human Health. Molecules 2019, 24, 2001. [CrossRef]

58. Corona, G.; Tzounis, X.; Dessì, M.A.; Deiana, M.; Debnam, E.S.; Visioli, F.; Spencer, J.P.E. The Fate of Olive Oil Polyphenols in the Gastrointestinal Tract: Implications of Gastric and Colonic Microflora-Dependent Biotransformation. Free. Radic. Res. 2006, 40, 647-658. [CrossRef] [PubMed]

59. Del Boccio, P.; Di Deo, A.; De Curtis, A.; Celli, N.; Iacoviello, L.; Rotilio, D. Liquid Chromatography-Tandem Mass Spectrometry Analysis of Oleuropein and Its Metabolite Hydroxytyrosol in rat Plasma and Urine after Oral Administration. J. Chromatogr. B 2003, 785, 47-56. [CrossRef]

60. Bazoti, F.N.; Gikas, E.; Tsarbopoulos, A. Simultaneous Quantification of Oleuropein and its Metabolites in Rat Plasma by Liquid Chromatography Electrospray Ionization Tandem Mass Spectrometry. Biomed. Chromatogr. 2010, 24, 506-515. [CrossRef]

61. Lin, P.; Qian, W.; Wang, X.; Cao, L.; Li, S.; Qian, T. The Biotransformation of Oleuropein in Rats. Biomed. Chromatogr. 2013, 27, 1162-1167. [CrossRef] [PubMed]

62. Mosele, J.I.; Macià, A.; Motilva, M.-J. Molecules Metabolic and Microbial Modulation of the Large Intestine Ecosystem by Non-Absorbed Diet Phenolic Compounds: A Review. Molecules 2015, 20, 17429-17468. [CrossRef]

63. De Bock, M.; Thorstensen, E.B.; Derraik, J.G.B.; Henderson, H.V.; Hofman, P.L.; Cutfield, W.S. Human Absorption and Metabolism of Oleuropein and Hydroxytyrosol Ingested as Olive (Olea europaea L.) Leaf Extract. Mol. Nutr. Food Res. 2013, 57, 2079-2085. [CrossRef]

64. Pinto, J.; Paiva-Martins, F.; Corona, G.; Debnam, E.S.; Oruna-Concha, M.J.; Vauzour, D.; Gordon, M.H.; Spencer, J.P.E. Absorption and Metabolism of Olive Oil Secoiridoids in the Small Intestine. Br. J. Nutr. 2011, 105, 1607-1618. [CrossRef]

65. Cicerale, S.; Conlan, X.A.; Sinclair, A.J.; Keast, R.S.J. Chemistry and Health of Olive Oil Phenolics. Crit. Rev. Food Sci. Nutr 2009, 49, 218-236. [CrossRef] [PubMed]

66. Hazas, M.-C.L.D.L.; Piñol, C.; Macià, A.; Romero, M.-P.; Pedret, A.; Solà, R.; Rubio, L.; Motilva, M.-J. Differential Absorption and Metabolism of Hydroxytyrosol and its Precursors Oleuropein and Secoiridoids. J. Funct. Foods 2016, 22, 52-63. [CrossRef]

67. Tan, H.-W.; Tuck, K.L.; Stupans, I.; Hayball, P.J. Simultaneous Determination of Oleuropein and Hydroxytyrosol in Rat Plasma Using Liquid Chromatography with Fluorescence Detection. J. Chromatogr. B 2003, 785, 187-191. [CrossRef] 
68. Hazas, M.-C.L.D.L.; Piñol, C.; Macià, A.; Motilva, M.-J. Hydroxytyrosol and the Colonic Metabolites Derived from Virgin Olive Oil Intake Induce Cell Cycle Arrest and Apoptosis in Colon Cancer Cells. J. Agric. Food Chem. 2017, 65, 6467-6476. [CrossRef] [PubMed]

69. Angeloni, C.; Malaguti, M.; Barbalace, M.C.; Hrelia, S. Bioactivity of Olive Oil Phenols in Neuroprotection. Int. J. Mol. Sci. 2017, 18, 2230. [CrossRef] [PubMed]

70. Romero, C.; Medina, E.; Vargas, J.; Brenes, M.; De Castro, A. In Vitro Activity of Olive Oil Polyphenols againstHelicobacter pylori. J. Agric. Food Chem. 2007, 55, 680-686. [CrossRef]

71. Silva, S.; Garcia-Aloy, M.; Figueira, M.E.; Combet, E.; Mullen, W.; Bronze, M.R. High Resolution Mass Spectrometric Analysis of Secoiridoids and Metabolites as Biomarkers of Acute Olive Oil Intake-An Approach to Study Interindividual Variability in Humans. Mol. Nutr. Food Res. 2018, 62, 1700065. [CrossRef]

72. García-Villalba, R.; Carrasco-Pancorbo, A.; Oliveras-Ferraros, C.; Vázquez-Martín, A.; Menendez, J.A.; Carretero, A.S.; Fernández-Gutiérrez, A. Characterization and Quantification of Phenolic Compounds of Extra-Virgin Olive Oils with Anticancer Properties by a Rapid and Resolutive LC-ESI-TOF MS Method. J. Pharm. Biomed. Anal. 2010, 51, 416-429. [CrossRef]

73. Naruszewicz, M.; Czerwinska, M.; Kiss, A. Oleacein. Translation from Mediterranean Diet to Potential Antiatherosclerotic Drug. Curr. Pharm. Des. 2014, 21, 1205-1212. [CrossRef]

74. Willett, W.C.; Sacks, F.; Trichopoulou, A.; Drescher, G.; Ferro-Luzzi, A.; Helsing, E.; Trichopoulos, D. Mediterranean Diet Pyramid: A Cultural Model for Healthy Eating. Am. J. Clin. Nutr. 1995, 61, 61. [CrossRef] [PubMed]

75. Dydjow-Bendek, D.; Zagoźdźon, P. Total Dietary Fats, Fatty Acids, and Omega-3/Omega-6 Ratio as Risk Factors of Breast Cancer in the Polish Population-A Case-Control Study. In Vivo 2020, 34, 423-431. [CrossRef] [PubMed]

76. Wang, J.; Wang, C. Dietary Fat Intake and Risk of Bladder Cancer: Evidence from a Meta-Analysis of Observational Studies. Cell. Mol. Boil. 2019, 65, 5-9. [CrossRef]

77. Grosso, G.; Buscemi, S.; Galvano, F.; Mistretta, A.; Marventano, S.; La Vela, V.; Drago, F.; Gangi, S.; Basile, F.; Biondi, A. Mediterranean Diet and Cancer: Epidemiological Evidence and Mechanism of Selected Aspects. BMC Surg. 2013, 13, S14. [CrossRef]

78. Solinas, G.; Germano, G.; Mantovani, A.; Allavena, P. Tumor-Associated Macrophages (TAM) as Major Players of the Cancer-Related Inflammation. J. Leukoc. Boil. 2009, 86, 1065-1073. [CrossRef]

79. Hamdi, H.K.; Castellon, R. Oleuropein, A Non-Toxic Olive Iridoid, Is an Anti-Tumor Agent and Cytoskeleton Disruptor. Biochem. Biophys. Res. Commun. 2005, 334, 769-778. [CrossRef]

80. Notarnicola, M.; Pisanti, S.; Tutino, V.; Bocale, D.; Rotelli, M.T.; Gentile, A.; Memeo, V.; Bifulco, M.; Perri, E.; Caruso, M.G. Effects of Olive Oil Polyphenols on Fatty Acid Synthase Gene Expression and Activity in Human Colorectal Cancer Cells. Genes Nutr. 2011, 6, 63-69. [CrossRef]

81. Cárdeno, A.; Sánchez-Hidalgo, M.; Rosillo, M.A.; De La Lastra, C.A. Oleuropein, a Secoiridoid Derived from Olive Tree, Inhibits the Proliferation of Human Colorectal Cancer Cell Through Downregulation of HIF-1 $\alpha$. Nutr. Cancer 2013, 65, 147-156. [CrossRef]

82. Hassan, Z.K.; Elamin, M.H.; Daghestani, M.H.; Omer, S.A.; Al-Olayan, E.M.; Elobeid, M.A.; Virk, P.; Mohammed, O.B. Oleuropein Induces Anti-Metastatic Effects in Breast Cancer. Asian Pac. J. Cancer Prev. 2012, 13, 4555-4559. [CrossRef]

83. Elamin, M.H.; Daghestani, M.H.; Omer, S.A.; A Elobeid, M.; Virk, P.; Al-Olayan, E.M.; Hassan, Z.K.; Mohammed, O.B.; Aboussekhra, A. Olive Oil Oleuropein Has Anti-Breast Cancer Properties with Higher Efficiency on ER-Negative Cells. Food Chem. Toxicol. 2013, 53, 310-316. [CrossRef]

84. Chimento, A.; Casaburi, I.; Rosano, C.; Avena, P.; De Luca, A.; Campana, C.; Martire, E.; Santolla, M.F.; Maggiolini, M.; Pezzi, V.; et al. Oleuropein and Hydroxytyrosol Activate GPER/ GPR30-Dependent Pathways Leading to Apoptosis of ER-Negative SKBR3 Breast Cancer Cells. Mol. Nutr. Food Res. 2014, 58, 478-489. [CrossRef] [PubMed]

85. Hassan, Z.K.; Elamin, M.H.; Omer, S.A.; Daghestani, M.H.; Al-Olayan, E.S.; Elobeid, M.A.; Virk, P. Oleuropein Induces Apoptosis via the p53 Pathway in Breast Cancer Cells. Asian Pac. J. Cancer Prev. 2014, 14, 6739-6742. [CrossRef] [PubMed]

86. Liu, L.; Ahn, K.S.; Shanmugam, M.K.; Wang, H.; Shen, H.; Arfuso, F.; Chinnathambi, A.; Alharbi, S.A.; Chang, Y.; Sethi, G.; et al. Oleuropein Induces Apoptosis via Abrogating NF-кB Activation Cascade in Estrogen Receptor-Negative Breast Cancer Cells. J. Cell. Biochem. 2018, 120, 4504-4513. [CrossRef] [PubMed] 
87. Choupani, J.; Alivand, M.R.M.; Derakhshan, S.; Zaeifizadeh, M.S.; Khaniani, M. Oleuropein Inhibits Migration Ability Through Suppression of Epithelial-Mesenchymal Transition and Synergistically Enhances Doxorubicin-Mediated Apoptosis in MCF-7 Cells. J. Cell. Physiol. 2019, 234, 9093-9104. [CrossRef]

88. Bayat, S.; Derakhshan, S.M.; Derakhshan, N.M.; Khaniani, M.S.; Alivand, M.R. Downregulation ofHDAC2andHDAC3via oleuropein as a Potent Prevention and Therapeutic Agent in MCF-7 Breast Cancer Cells. J. Cell. Biochem. 2019, 120, 9172-9180. [CrossRef]

89. Mansouri, N.; Alivand, M.R.; Bayat, S.; Khaniani, M.S.; Derakhshan, S.M. The Hopeful Anticancer Role of Oleuropein in Breast Cancer through Histone Deacetylase Modulation. J. Cell. Biochem. 2019, 120, 17042-17049. [CrossRef]

90. Lu, H.-Y.; Zhu, J.-S.; Zhang, Z.; Shen, W.-J.; Jiang, S.; Long, Y.-F.; Wu, B.; Ding, T.; Huan, F.; Wang, S.-L. Hydroxytyrosol and Oleuropein Inhibit Migration and Invasion of MDA-MB-231 Triple-Negative Breast Cancer Cell via Induction of Autophagy. Anticancer Agents Med. Chem. 2019, 19, 1983-1990. [CrossRef]

91. Przychodzen, P.; Kuban-Jankowska, A.; Wyszkowska, R.; Barone, G.; Bosco, G.L.; Celso, F.L.; Kamm, A.; Daca, A.; Kostrzewa, T.; Gorska-Ponikowska, M. PTP1B Phosphatase as a Novel Target of Oleuropein Activity in MCF-7 Breast Cancer Model. Toxicol. Vitr. 2019, 61, 104624. [CrossRef]

92. Yan, C.-M.; Chai, E.-Q.; Cai, H.-Y.; Miao, G.-Y.; Ma, W. Oleuropein Induces Apoptosis via Activation of Caspases and Suppression of Phosphatidylinositol 3-kinase/protein kinase B Pathway in HepG2 Human Hepatoma Cell Line. Mol. Med. Rep. 2015, 11, 4617-4624. [CrossRef]

93. Sherif, I.O.; Al-Gayyar, M.M. Oleuropein Potentiates Anti-Tumor Activity of Cisplatin Against HepG2 through Affecting proNGF/NGF Balance. Life Sci. 2018, 198, 87-93. [CrossRef]

94. Vanella, L.; Acquaviva, R.; Di Giacomo, C.; Sorrenti, V.; Galvano, F.; Santangelo, R.; Cardile, V.; Gangia, S.; D'Orazio, N.; Abraham, N.G. Antiproliferative Effect of Oleuropein in Prostate Cell Lines. Int. J. Oncol. 2012, 41,31-38. [CrossRef] [PubMed]

95. Bulotta, S.; Corradino, R.; Celano, M.; Maiuolo, J.; D'Agostino, M.; Oliverio, M.; Procopio, A.; Filetti, S.; Russo, D. Antioxidant and Antigrowth Action of Peracetylated Oleuropein in Thyroid Cancer Cells. J. Mol. Endocrinol. 2013, 51, 181-189. [CrossRef] [PubMed]

96. Yao, J.; Wu, J.; Yang, X.; Yang, J.; Zhang, Y.; Du, L. Oleuropein Induced Apoptosis in HeLa Cells via a Mitochondrial Apoptotic Cascade Associated with Activation of the c-Jun NH2-Terminal Kinase. J. Pharmacol. Sci. 2014, 125, 300-311. [CrossRef] [PubMed]

97. Seçme, M.; Eroğlu, C.; Dodurga, Y.; Bağc1, G. Investigation of Anticancer Mechanism of Oleuropein via Cell Cycle and Apoptotic Pathways in SH-SY5Y Neuroblastoma Cells. Gene 2016, 585, 93-99. [CrossRef] [PubMed]

98. Liu, M.; Wang, J.; Huang, B.; Chen, A.; Li, X. Oleuropein Inhibits the Proliferation and Invasion of Glioma Cells via Suppression of the AKT Signaling Pathway. Oncol. Rep. 2016, 36, 2009-2016. [CrossRef] [PubMed]

99. Xu, T.; Xiao, D. Oleuropein Enhances Radiation Sensitivity of Nasopharyngeal Carcinoma by Downregulating PDRG1 through HIF1 $\alpha$-repressed microRNA-519d. J. Exp. Clin. Cancer Res. 2017, 36, 3. [CrossRef]

100. Cao, S.; Zhu, X.; Du, L. P38 MAP Kinase is Involved in Oleuropein-Induced Apoptosis in A549 Cells by a Mitochondrial Apoptotic cascade. Biomed. Pharmacother. 2017, 95, 1425-1435. [CrossRef]

101. Wang, W.; Wu, J.; Zhang, Q.; Li, X.; Zhu, X.; Wang, Q.; Cao, S.; Du, L. Mitochondria-Mediated Apoptosis Was Induced by Oleuropein in H1299 Cells Involving Activation of p38 MAP Kinase. J. Cell. Biochem. 2019, 120, 5480-5494. [CrossRef]

102. Antognelli, C.; Frosini, R.; Santolla, M.F.; Peirce, M.J.; Talesa, V.N. Oleuropein-Induced Apoptosis Is Mediated by Mitochondrial Glyoxalase 2 in NSCLC A549 Cells: A Mechanistic Inside and a Possible Novel Nonenzymatic Role for an Ancient Enzyme. Oxidative Med. Cell. Longev. 2019, 2019, 8576961. [CrossRef]

103. Goldsmith, C.D.; Bond, D.R.; Jankowski, H.; Weidenhofer, J.; Stathopoulos, C.E.; Roach, P.D.; Scarlett, C.J. The Olive Biophenols Oleuropein and Hydroxytyrosol Selectively Reduce Proliferation, Influence the Cell Cycle, and Induce Apoptosis in Pancreatic Cancer Cells. Int. J. Mol. Sci. 2018, 19, 1937. [CrossRef]

104. Ruzzolini, J.; Peppicelli, S.; Andreucci, E.; Bianchini, F.; Scardigli, A.; Romani, A.; La Marca, G.; Nediani, C.; Calorini, L. Oleuropein, the Main Polyphenol of Olea europaea Leaf Extract, Has an Anti-Cancer Effect on Human BRAF Melanoma Cells and Potentiates the Cytotoxicity of Current Chemotherapies. Nutrients 2018, 10, 1950. [CrossRef] [PubMed]

105. Zhang, F.; Zhang, M. Oleuropein Inhibits Esophageal Cancer through Hypoxic Suppression of BTG3 mRNA. Food Funct. 2019, 10, 978-985. [CrossRef] [PubMed] 
106. Przychodzen, P.; Wyszkowska, R.; Gorzynik-Debicka, M.; Kostrzewa, T.; Kuban-Jankowska, A.; Gorska-Ponikowska, M. Anticancer Potential of Oleuropein, the Polyphenol of Olive Oil, With 2-Methoxyestradiol, Separately or in Combination, in Human Osteosarcoma Cells. Anticancer. Res. 2019, 39, 1243-1251. [CrossRef] [PubMed]

107. Barzegar, F.; Zaefizadeh, M.; Yari, R.; Salehzadeh, A. Synthesis of Nano-Paramagnetic Oleuropein to Induce KRAS Over-Expression: A New Mechanism to Inhibit AGS Cancer Cells. Medicina (Kaunas) 2019, 55, E388. [CrossRef]

108. Rigacci, S.; Miceli, C.; Nediani, C.; Berti, A.; Cascella, R.; Pantano, D.; Nardiello, P.; Luccarini, I.; Casamenti, F.; Stefani, M. Oleuropein Aglycone Induces Autophagy via the AMPK/mTOR Signalling Pathway: A Mechanistic Insight. Oncotarget 2015, 6, 35344-35357. [CrossRef]

109. Khanal, P.; Oh, W.-K.; Yun, H.J.; Namgoong, G.M.; Ahn, S.-G.; Kwon, S.-M.; Choi, H.-K.; Choi, H.S. p-HPEA-EDA, a Phenolic Compound of Virgin Olive Oil, Activates AMP-Activated Protein Kinase to Inhibit Carcinogenesis. Carcinogenesis 2011, 32, 545-553. [CrossRef]

110. Elnagar, A.; Sylvester, P.; El Sayed, K. (-)-Oleocanthal as a c-Met Inhibitor for the Control of Metastatic Breast and Prostate Cancers. Planta Medica 2011, 77, 1013-1019. [CrossRef]

111. Akl, M.R.; Ayoub, N.M.; Mohyeldin, M.M.; Busnena, B.A.; Foudah, A.I.; Liu, Y.-Y.; Sayed, K.A.E. Olive Phenolics as c-Met Inhibitors: (-)-Oleocanthal Attenuates Cell Proliferation, Invasiveness, and Tumor Growth in Breast Cancer Models. PLOS ONE 2014, 9, e97622. [CrossRef]

112. Khanfar, M.A.; Bardaweel, S.K.; Akl, M.R.; Sayed, K.A. El Olive Oil-derived Oleocanthal as Potent Inhibitor of Mammalian Target of Rapamycin: Biological Evaluation and Molecular Modeling Studies. Phyther. Res. 2015, 29, 1776-1782. [CrossRef]

113. Tajmim, A.; Siddique, A.B.; Sayed, E.; El Sayed, K. Optimization of Taste-Masked (-)-Oleocanthal Effervescent Formulation with Potent Breast Cancer Progression and Recurrence Suppressive Activities. Pharmaceutics 2019, 11, E515. [CrossRef]

114. Qusa, M.H.; Siddique, A.B.; Nazzal, S.; El Sayed, K.A. Novel Olive Oil Phenolic (-)-Oleocanthal (+)-Xylitol-Based Solid Dispersion Formulations with Potent Oral Anti-Breast Cancer Activities. Int. J. Pharm. 2019, 569, 118596. [CrossRef] [PubMed]

115. Siddique, A.B.; Ebrahim, H.Y.; Akl, M.R.; Ayoub, N.M.; Goda, A.A.; Mohyeldin, M.M.; Nagumalli, S.K.; Hananeh, W.M.; Liu, Y.-Y.; Meyer, S.A.; et al. (-)-Oleocanthal Combined with Lapatinib Treatment Synergized against HER-2 Positive Breast Cancer in Vitro and in Vivo. Nutrients 2019, 11, 412. [CrossRef] [PubMed]

116. Diez-Bello, R.; Jardin, I.; Lopez, J.J.; El Haouari, M.; Ortega-Vidal, J.; Altarejos, J.; Salido, G.M.; Salido, S.; Rosado, J.A. (-)-Oleocanthal Inhibits Proliferation and Migration by Modulating Ca2 ${ }^{+}$Entry through TRPC6 in Breast Cancer Cells. Biochim. Biophys. Acta - Mol. Cell Res. 2019, 1866, 474-485. [CrossRef]

117. Pei, T.; Meng, Q.; Han, J.; Sun, H.; Li, L.; Song, R.; Sun, B.; Pan, S.; Liang, D.; Liu, L. (-)-Oleocanthal Inhibits Growth and Metastasis by Blocking Activation of STAT3 in Human Hepatocellular Carcinoma. Oncotarget 2016, 7, 43475-43491. [CrossRef] [PubMed]

118. De Stefanis, D.; Scimè, S.; Accomazzo, S.; Catti, A.; Occhipinti, A.; Bertea, C.M.; Costelli, P.; Stefanis, D. Anti-Proliferative Effects of an Extra-Virgin Olive Oil Extract Enriched in Ligstroside Aglycone and Oleocanthal on Human Liver Cancer Cell Lines. Cancers 2019, 11, 1640. [CrossRef] [PubMed]

119. Margarucci, L.; Cassiano, C.; Mozzicafreddo, M.; Angeletti, M.; Riccio, R.; Monti, M.C.; Tosco, A.; Casapullo, A. Chemical Proteomics-Driven Discovery of Oleocanthal as an Hsp90 Inhibitor. Chem. Commun. 2013, 49, 5844. [CrossRef]

120. Gu, Y.; Wang, J.; Peng, L. (-)-Oleocanthal Exerts Anti-Melanoma Activities and Inhibits STAT3 Signaling Pathway. Oncol. Rep. 2017, 37, 483-491. [CrossRef]

121. Polini, B.; Digiacomo, M.; Carpi, S.; Bertini, S.; Gado, F.; Saccomanni, G.; Macchia, M.; Nieri, P.; Manera, C.; Fogli, S. Oleocanthal and Oleacein Contribute to the in Vitro Therapeutic Potential of in Oil-Derived Extracts in Non-Melanoma Skin Cancer. Toxicol. Vitr. 2018, 52, 243-250. [CrossRef]

122. Juli, G.; Oliverio, M.; Bellizzi, D.; Cantafio, M.E.G.; Grillone, K.; Passarino, G.; Colica, C.; Nardi, M.; Rossi, M.; Procopio, A.; et al. Anti-tumor Activity and Epigenetic Impact of the Polyphenol Oleacein in Multiple Myeloma. Cancers 2019, 11, 990. [CrossRef]

123. Kimura, Y.; Sumiyoshi, M. Olive Leaf Extract and Its Main Component Oleuropein Prevent Chronic Ultraviolet B Radiation-Induced Skin Damage and Carcinogenesis in Hairless Mice. J. Nutr. 2009, 139, 2079-2086. [CrossRef] 
124. Giner, E.; Recio, M.C.; Ríos, J.L.; Cerdá-Nicolás, J.M.; Giner, R.M. Chemopreventive Effect of Oleuropein in Colitis-Associated Colorectal Cancer in c57bl/6 Mice. Mol. Nutr. Food Res. 2016, 60, 242-255. [CrossRef] [PubMed]

125. Geyikoğlu, F.; Çolak, S.; Türkez, H.; Bakır, M.; Koç, K.; Hosseinigouzdagani, M.K.; Çeriğ, S.; Sönmez, M. Oleuropein Ameliorates Cisplatin-induced Hematological Damages Via Restraining Oxidative Stress and DNA Injury. Indian J. Hematol. Blood Transfus. 2017, 33, 348-354. [CrossRef] [PubMed]

126. Song, H.; Lim, Y.; Jung, J.I.; Cho, H.J.; Park, S.Y.; Kwon, G.T.; Kang, Y.-H.; Lee, K.W.; Choi, M.-S.; Park, J.H.Y. Dietary Oleuropein Inhibits Tumor Angiogenesis and Lymphangiogenesis in the B16F10 Melanoma Allograft Model: A Mechanism for the Suppression of High-Fat Diet-Induced Solid Tumor Growth and Lymph Node Metastasis. Oncotarget 2017, 8, 32027-32042. [CrossRef] [PubMed]

127. Koc, K.; Bakir, M.; Geyikoglu, F.; Cerig, S. Therapeutic Effects of Oleuropein on Cisplatin-Induced Pancreas Injury in Rats. J. Cancer Res. Ther. 2018, 14, 671. [CrossRef]

128. Elamin, M.H.; Elmahi, A.B.; Daghestani, M.H.; Al-Olayan, E.M.; Al-Ajmi, R.A.; Alkhuriji, A.F.; Hamed, S.S.; Elkhadragy, M.F. Synergistic Anti-Breast-Cancer Effects of Combined Treatment with Oleuropein and Doxorubicin in Vivo. Altern. Ther. Health Med. 2019, 25, 17-24.

129. Siddique, A.B.; Ayoub, N.M.; Tajmim, A.; Meyer, S.A.; Hill, R.A.; El Sayed, K.A. (-)-Oleocanthal Prevents Breast Cancer Locoregional Recurrence After Primary Tumor Surgical Excision and Neoadjuvant Targeted Therapy in Orthotopic Nude Mouse Models. Cancers 2019, 11, 637. [CrossRef]

130. Sherif, I.O. The Effect of Natural Antioxidants in Cyclophosphamide-Induced Hepatotoxicity: Role of Nrf2/HO-1 Pathway. Int. Immunopharmacol. 2018, 61, 29-36. [CrossRef]

131. Goren, L.; Zhang, G.; Kaushik, S.; Breslin, P.A.S.; Du, Y.-C.N.; Foster, D.A. (-)-Oleocanthal and (-)-Oleocanthal-Rich Olive Oils Induce Lysosomal Membrane Permeabilization in Cancer Cells. PLOS ONE 2019, 14, e0216024. [CrossRef]

132. Siddique, A.B.; Ebrahim, H.; Mohyeldin, M.; Qusa, M.; Batarseh, Y.; Fayyad, A.; Tajmim, A.; Nazzal, S.; Kaddoumi, A.; El Sayed, K. Novel Liquid-Liquid Extraction and Self-Emulsion Methods for Simplified Isolation of Extra-Virgin Olive Oil Phenolics with Emphasis on (-)-Oleocanthal and Its Oral Anti-Breast Cancer Activity. PLOS ONE 2019, 14, e0214798. [CrossRef]

133. Scotece, M.; Gómez, R.; Conde, J.; Lopez, V.; Gomez-Reino, J.J.; Lago, F.; Smith, A.B.; Gualillo, O. Further Evidence for the Anti-Inflammatory Activity of Oleocanthal: Inhibition of MIP-1 $\alpha$ and IL-6 in J774 Macrophages and in ATDC5 Chondrocytes. Life Sci. 2012, 91, 1229-1235. [CrossRef]

134. Wang, H.; Naghavi, M.; Allen, C.; Barber, R.M.; A Bhutta, Z.; Carter, A.; Casey, D.C.; Charlson, F.J.; Chen, A.Z.; Coates, M.M.; et al. Global, Regional, and National Life Expectancy, All-Cause Mortality, and Cause-Specific Mortality for 249 Causes of Death, 1980-2015: A Systematic analysis for the Global Burden of Disease Study 2015. Lancet 2016, 388, 1459-1544. [CrossRef]

135. Reboredo-Rodríguez, P.; González-Barreiro, C.; Cancho-Grande, B.; Forbes-Hernandez, T.Y.; Gasparrini, M.; Afrin, S.; Cianciosi, D.; Carrasco-Pancorbo, A.; Simal-Gándara, J.; Giampieri, F.; et al. Characterization of Phenolic Extracts from Brava Extra Virgin Olive Oils and Their Cytotoxic Effects on MCF-7 Breast Cancer Cells. Food Chem. Toxicol. 2018, 119, 73-85. [CrossRef] [PubMed]

136. Crespo, M.C.; Tomé-Carneiro, J.; Dávalos, A.; Visioli, F. Pharma-Nutritional Properties of Olive Oil Phenols. Transfer of New Findings to Human Nutrition. Foods 2018, 7, 90. [CrossRef] [PubMed]

137. Catalán, Ú.; Rubio, L.; Hazas, M.-C.L.D.L.; Herrero, P.; Nadal, P.; Canela, N.; Pedret, A.; Motilva, M.-J.; Solà, R. Hydroxytyrosol and Its Complex Forms (Secoiridoids) Modulate Aorta and Heart Proteome in Healthy Rats: Potential Cardio-Protective Effects. Mol. Nutr. Food Res. 2016, 60, 2114-2129. [CrossRef] [PubMed]

138. Visioli, F.; Bellomo, G.; Montedoro, G.; Galli, C. Low Density Lipoprotein Oxidation Is Inhibited in Vitro by Olive Oil Constituents. Atherosclerosis 1995, 117, 25-32. [CrossRef]

139. Visioli, F.; Bellosta, S.; Galli, C. Oleuropein, the Bitter Principle of Olives, Enhances Nitric Oxide Production by Mouse Macrophages. Life Sci. 1998, 62, 541-546. [CrossRef]

140. Parzonko, A.; Czerwińska, M.E.; Kiss, A.K.; Naruszewicz, M. Oleuropein and Oleacein may Restore Biological Functions of Endothelial Progenitor Cells Impaired by Angiotensin II via Activation of Nrf2/heme Oxygenase-1 Pathway. Phytomedicine 2013, 20, 1088-1094. [CrossRef]

141. Dell'Agli, M.; Fagnani, R.; Mitro, N.; Scurati, S.; Masciadri, M.; Mussoni, L.; Galli, G.V.; Bosisio, E.; Crestani, M.; De Fabiani, E.; et al. Minor Components of Olive Oil Modulate Proatherogenic Adhesion Molecules Involved in Endothelial Activation. J. Agric. Food Chem. 2006, 54, 3259-3264. [CrossRef] 
142. Leri, M.; Nosi, D.; Natalello, A.; Porcari, R.; Ramazzotti, M.; Chiti, F.; Bellotti, V.; Doglia, S.M.; Stefani, M.; Bucciantini, M. The Polyphenol Oleuropein Aglycone Hinders the Growth of Toxic Transthyretin Amyloid Assemblies. J. Nutr. Biochem. 2016, 30, 153-166. [CrossRef]

143. Czerwińska, M.E.; Kiss, A.K.; Naruszewicz, M. Inhibition of Human Neutrophils NEP Activity, CD11b/CD18 Expression and Elastase Release by 3,4-dihydroxyphenylethanol-elenolic Acid Dialdehyde, Oleacein. Food Chem. 2014, 153, 1-8. [CrossRef]

144. Filipek, A.; Czerwińska, M.E.; Kiss, A.K.; Wrzosek, M.; Naruszewicz, M. Oleacein Enhances Anti-Inflammatory Activity of Human Macrophages by Increasing CD163 Receptor Expression. Phytomedicine 2015, 22, 1255-1261. [CrossRef] [PubMed]

145. Manna, C.; Migliardi, V.; Golino, P.; Scognamiglio, A.; Galletti, P.; Chiariello, M.; Zappia, V. Oleuropein Prevents Oxidative Myocardial Injury Induced by Ischemia and Reperfusion. J. Nutr. Biochem. 2004, 15, 461-466. [CrossRef] [PubMed]

146. Andreadou, I.; Iliodromitis, E.K.; Mikros, E.; Constantinou, M.; Agalias, A.; Magiatis, P.; Skaltsounis, A.L.; Kamber, E.; Tsantili-Kakoulidou, A.; Kremastinos, D.T. The Olive Constituent Oleuropein Exhibits Anti-Ischemic, Antioxidative, and Hypolipidemic Effects in Anesthetized Rabbits. J. Nutr. 2006, 136, 2213-2219. [CrossRef] [PubMed]

147. Andreadou, I.; Sigala, F.; Iliodromitis, E.K.; Papaefthimiou, M.; Sigalas, C.; Aligiannis, N.; Savvari, P.; Gorgoulis, V.; Papalabros, E.; Kremastinos, D.T. Acute Doxorubicin Cardiotoxicity Is Successfully Treated with the Phytochemical Oleuropein through Suppression of Oxidative and Nitrosative Stress. J. Mol. Cell. Cardiol. 2007, 42, 549-558. [CrossRef]

148. Andreadou, I.; Papaefthimiou, M.; Zira, A.; Constantinou, M.; Sigala, F.; Skaltsounis, A.-L.; Tsantili-Kakoulidou, A.; Iliodromitis, E.K.; Kremastinos, D.T.; Mikros, E. Metabonomic Identification of Novel Biomarkers in Doxorubicin Cardiotoxicity and Protective Effect of the Natural Antioxidant Oleuropein. NMR Biomed. 2009, 22, 585-592. [CrossRef]

149. Andreadou, I.; Mikros, E.; Ioannidis, K.; Sigala, F.; Naka, K.; Kostidis, S.; Farmakis, D.; Tenta, R.; Kavantzas, N.; Bibli, S.-I.; et al. Oleuropein Prevents Doxorubicin-Induced Cardiomyopathy Interfering with Signaling Molecules and Cardiomyocyte Metabolism. J. Mol. Cell. Cardiol. 2014, 69, 4-16. [CrossRef]

150. Wang, L.; Geng, C.; Jiang, L.; Gong, D.; Liu, D.; Yoshimura, H.; Zhong, L. The Anti-Atherosclerotic Effect of Olive Leaf Extract Is Related to Suppressed Inflammatory Response in Rabbits with Experimental Atherosclerosis. Eur. J. Nutr. 2008, 47, 235-243. [CrossRef]

151. Ebaid, G.M.; Seiva, F.R.; Rocha, K.K.; A Souza, G.; Novelli, E.L. Effects of Olive Oil and Its Minor Phenolic Constituents on Obesity-Induced Cardiac Metabolic Changes. Nutr. J. 2010, 9, 46. [CrossRef]

152. Khalili, A.; Nekooeian, A.A.; Khosravi, M.B. Oleuropein Improves Glucose Tolerance and Lipid Profile in Rats with Simultaneous Renovascular Hypertension and Type 2 Diabetes. J. Asian Nat. Prod. Res. 2017, 19, 1011-1021. [CrossRef]

153. Nekooeian, A.A.; Khalili, A.; Khosravi, M.B. Oleuropein Offers Cardioprotection in Rats with Simultaneous Type 2 Diabetes and Renal Hypertension. Indian J. Pharmacol. 2014, 46, 398-403. [CrossRef]

154. Nekooeian, A.A.; Khalili, A.; Khosravi, M.B. Effects of Oleuropein in Rats with Simultaneous Type 2 Diabetes and Renal Hypertension: A Study of Antihypertensive Mechanisms. J. Asian Nat. Prod. Res. 2014, 16, 953-962. [CrossRef] [PubMed]

155. Ivanov, M.; Vajic, U.-J.; Mihailovic-Stanojevic, N.; Miloradovic, Z.; Jovovic, D.; Grujic-Milanovic, J.; Karanovic, D.; Dekanski, D. Highly Potent Antioxidant Olea europaea L. Leaf Extract Affects Carotid and Renal Haemodynamics in Experimental Hypertension: The Role of Oleuropein. Excli J. 2018, 17, $29-44$. [PubMed]

156. Jemai, H.; Bouaziz, M.; Fki, I.; El Feki, A.; Sayadi, S. Hypolipidimic and Antioxidant Activities of Oleuropein and Its Hydrolysis Derivative-Rich Extracts from Chemlali Olive Leaves. Chem. Interactions 2008, 176, 88-98. [CrossRef] [PubMed]

157. Miceli, C.; Santin, Y.; Manzella, N.; Coppini, R.; Berti, A.; Stefani, M.; Parini, A.; Mialet-Perez, J.; Nediani, C. Oleuropein Aglycone Protects against MAO-A-Induced Autophagy Impairment and Cardiomyocyte Death through Activation of TFEB. Oxidative Med. Cell. Longev. 2018, 2018, 8067592. [CrossRef]

158. Margheri, F.; Menicacci, B.; Laurenzana, A.; Del Rosso, M.; Fibbi, G.; Cipolleschi, M.G.; Ruzzolini, J.; Nediani, C.; Mocali, A.; Giovannelli, L. Oleuropein Aglycone Attenuates the Pro-Angiogenic Phenotype of Senescent Fibroblasts: A Functional Study in Endothelial Cells. J. Funct. Foods 2019, 53, 219-226. [CrossRef] 
159. Covas, M.-I.; Nyyssönen, K.; E Poulsen, H.; Kaikkonen, J.; Zunft, H.-J.F.; Kiesewetter, H.; Gaddi, A.; De La Torre, R.; Mursu, J.; Bäumler, H.; et al. The Effect of Polyphenols in Olive Oil on Heart Disease Risk Factors: A Randomized Trial. Ann. Intern. Med. 2006, 145, 333-341. [CrossRef]

160. Susalit, E.; Agus, N.; Effendi, I.; Tjandrawinata, R.R.; Nofiarny, D.; Perrinjaquet-Moccetti, T.; Verbruggen, M. Olive (Olea europaea) Leaf Extract Effective in Patients with Stage-1 Hypertension: Comparison with Captopril. Phytomedicine 2011, 18, 251-258. [CrossRef]

161. Stock, J. HDL Function and Cardiovascular Risk: Debate Continues ... . Atherosclerosis 2013, $229,38-41$. [CrossRef]

162. Casapullo, A.; Del Gaudio, F.; Capolupo, A.; Cassiano, C.; Chiara Monti, M. Multi-Target Profile of Oleocanthal, An Extra-Virgin Olive Oil Component. Curr. Bioact. Compd. 2016, 12, 3-9. [CrossRef]

163. Beauchamp, G.K.; Keast, R.S.J.; Morel, D.; Lin, J.; Pika, J.; Han, Q.; Lee, C.-H.; Smith, A.B.; Breslin, P.A.S. Ibuprofen-Like activIty in Extra-Virgin Olive Oil. Nature 2005, 437, 45-46. [CrossRef]

164. Scotece, M.; Conde, J.; Abella, V.; López, V.; Francisco, V.; Ruiz, C.; Campos, V.; Lago, F.; Gomez, R.; Pino, J.; et al. Oleocanthal Inhibits Catabolic and Inflammatory Mediators in LPS-Activated Human Primary Osteoarthritis (OA) Chondrocytes Through MAPKs/NF-kB Pathways. Cell. Physiol. Biochem. 2018, 49, 2414-2426. [CrossRef] [PubMed]

165. Vinten-Johansen, J. Involvement of Neutrophils in the Pathogenesis of Lethal Myocardial Reperfusion Injury. Cardiovasc. Res. 2004, 61, 481-497. [CrossRef] [PubMed]

166. Filipek, A.; Czerwińska, M.E.; Kiss, A.K.; Polański, J.A.; Naruszewicz, M. Oleacein may Inhibit Destabilization of Carotid Plaques from Hypertensive Patients: Impact on high Mobility Group Protein-1. Phytomedicine 2017, 32, 68-73. [CrossRef] [PubMed]

167. Manoharan, S.; Guillemin, G.J.; Abiramasundari, R.S.; Essa, M.M.; Akbar, M. The Role of Reactive Oxygen Species in the Pathogenesis of Alzheimer's Disease, Parkinson's Disease, and Huntington's Disease: A Mini Review. Oxidative Med. Cell. Longev. 2016, 2016, 1-15. [CrossRef] [PubMed]

168. Wyss-Coray, T. Ageing, neurodegeneration and brain rejuvenation. Nature 2016, 539, 180-186. [CrossRef] [PubMed]

169. Stefani, M.; Rigacci, S. Beneficial Properties of Natural Phenols: Highlight on Protection against Pathological Conditions Associated with Amyloid Aggregation. BioFactors 2014, 40, 482-493. [CrossRef] [PubMed]

170. Capurso, A.; Crepaldi, G.; Capurso, C. Extra-Virgin Olive Oil, the Mediterranean Diet, and Neurodegenerative Diseases. In Benefits of the Mediterranean Diet in the Elderly Patient; Springer: Cham, Switzerland, 2018; pp. 81-95.

171. Pasban-Aliabadi, H.; Esmaeili-Mahani, S.; Sheibani, V.; Abbasnejad, M.; Mehdizadeh, A.; Yaghoobi, M.M. Inhibition of 6-Hydroxydopamine-Induced PC12 Cell Apoptosis by Olive (Olea europaea L.) Leaf Extract Is Performed by Its Main Component Oleuropein. Rejuvenation Res. 2013, 16, 134-142. [CrossRef]

172. Achour, I.; Arel-Dubeau, A.-M.; Renaud, J.; Legrand, M.; Attard, E.; Germain, M.; Martinoli, M.-G. Oleuropein Prevents Neuronal Death, Mitigates Mitochondrial Superoxide Production and Modulates Autophagy in a Dopaminergic Cellular Model. Int. J. Mol. Sci. 2016, 17, 1293. [CrossRef]

173. Leri, M.; Natalello, A.; Bruzzone, E.; Stefani, M.; Bucciantini, M. Oleuropein aglycone and hydroxytyrosol interfere differently with toxic A $\beta 1-42$ aggregation. Food Chem. Toxicol. 2019, 129, 1-12. [CrossRef]

174. Omar, S.H.; Scott, C.J.; Hamlin, A.S.; Obied, H.K. Olive Biophenols Reduces Alzheimer's Pathology in SH-SY5Y Cells and APPswe Mice. Int. J. Mol. Sci. 2019, 20, E125. [CrossRef] [PubMed]

175. Luccarini, I.; Dami, T.E.; Grossi, C.; Rigacci, S.; Stefani, M.; Casamenti, F. Oleuropein Aglycone Counteracts A $\beta 42$ Toxicity in the Rat Brain. Neurosci. Lett. 2014, 558, 67-72. [CrossRef] [PubMed]

176. Grossi, C.; Rigacci, S.; Ambrosini, S.; Dami, T.E.; Luccarini, I.; Traini, C.; Failli, P.; Berti, A.; Casamenti, F.; Stefani, M. The Polyphenol Oleuropein Aglycone Protects TgCRND8 Mice against Aß Plaque Pathology. PLOS ONE 2013, 8, e71702. [CrossRef] [PubMed]

177. Diomede, L.; Rigacci, S.; Romeo, M.; Stefani, M.; Salmona, M. Oleuropein Aglycone Protects Transgenic C. elegans Strains Expressing A 342 by Reducing Plaque Load and Motor Deficit. PLOS ONE 2013, 8, e58893. [CrossRef] [PubMed]

178. Rigacci, S.; Guidotti, V.; Bucciantini, M.; Nichino, D.; Relini, A.; Berti, A.; Stefani, M. A $\beta(1-42)$ Aggregates into Non-Toxic Amyloid Assemblies in the Presence of the Natural Polyphenol Oleuropein Aglycon. Curr. Alzheimer Res. 2011, 8, 841-852. [CrossRef] [PubMed] 
179. Pantano, D.; Luccarini, I.; Nardiello, P.; Servili, M.; Stefani, M.; Casamenti, F. Oleuropein Aglycone and Polyphenols from Olive Mill Waste Water Ameliorate Cognitive Deficits and Neuropathology. Br. J. Clin. Pharmacol. 2017, 83, 54-62. [CrossRef]

180. Batarseh, Y.S.; Kaddoumi, A. Oleocanthal-Rich Extra-Virgin Olive Oil Enhances Donepezil Effect by Reducing Amyloid- $\beta$ Load and Related Toxicity in a Mouse Model of Alzheimer's Disease. J. Nutr. Biochem. 2018, 55, 113-123. [CrossRef]

181. Qosa, H.; Batarseh, Y.S.; Mohyeldin, M.M.; El Sayed, K.A.; Keller, J.N.; Kaddoumi, A. Oleocanthal Enhances Amyloid- $\beta$ Clearance from the Brains of TgSwDI Mice and in Vitro across a Human Blood-Brain Barrier Model. ACS Chem. Neurosci. 2015, 6, 1849-1859. [CrossRef]

182. Abuznait, A.H.; Qosa, H.; Busnena, B.A.; El Sayed, K.A.; Kaddoumi, A. Olive-Oil-Derived Oleocanthal Enhances $\beta$-Amyloid Clearance as a Potential Neuroprotective Mechanism against Alzheimer's Disease: In Vitro and in Vivo Studies. ACS Chem. Neurosci. 2013, 4, 973-982. [CrossRef]

183. Mohammad-Beigi, H.; Aliakbari, F.; Sahin, C.; Lomax, C.; Tawfike, A.; Schafer, N.P.; Amiri-Nowdijeh, A.; Eskandari, H.; Møller, I.M.; Hosseini-Mazinani, M.; et al. Oleuropein Derivatives from Olive Fruit Extracts Reduce $\alpha$-Synuclein Fibrillation and Oligomer Toxicity. J. Boil. Chem. 2019, 294, 4215-4232. [CrossRef]

184. Prasanth, M.I.; Brimson, J.M.; Chuchawankul, S.; Sukprasansap, M.; Tencomnao, T. Antiaging, Stress Resistance, and Neuroprotective Efficacies of Cleistocalyx nervosum var. paniala Fruit Extracts Using Caenorhabditis elegans Model. Oxidative Med. Cell. Longev. 2019, 2019, 1-14. [CrossRef] [PubMed]

185. Chondrogianni, N.; Chinou, I.; Gonos, E.S. Anti-aging Properties of the Olive Constituent Oleuropein in Human Cells. In Olives and Olive Oil in Health and Disease Prevention; Elsevier: Amsterdam, The Netherlands, 2010; pp. 1335-1343.

186. Katsiki, M.; Chondrogianni, N.; Chinou, I.; Rivett, A.J.; Gonos, E.S. The Olive Constituent Oleuropein Exhibits Proteasome Stimulatory Properties in Vitro and Confers Life Span Extension of Human Embryonic Fibroblasts. Rejuvenation Res. 2007, 10, 157-172. [CrossRef] [PubMed]

187. Santiago-Mora, R.; Casado-Díaz, A.; De Castro, M.D.; Quesada-Gómez, J.M. Oleuropein Enhances Osteoblastogenesis and Inhibits Adipogenesis: The Effect on Differentiation in Stem Cells Derived from Bone Marrow. Osteoporos. Int. 2011, 22, 675-684. [CrossRef] [PubMed]

188. Remmen, H. Oxidative Damage to Mitochondria and Aging. Exp. Gerontol. 2001, 36, 957-968. [CrossRef]

189. Puel, C.; Quintin, A.; Agalias, A.; Mathey, J.; Obled, C.; Mazur, A.; Davicco, M.J.; Lebecque, P.; Skaltsounis, A.L.; Coxam, V. Olive Oil and Its Main Phenolic Micronutrient (Oleuropein) Prevent Inflammation-Induced Bone Loss in the Ovariectomised Rat. Br. J. Nutr. 2004, 92, 119-127. [CrossRef] [PubMed]

190. Nikou, T.; Liaki, V.; Stathopoulos, P.; Sklirou, A.D.; Tsakiri, E.N.; Jakschitz, T.; Bonn, G.; Trougakos, I.P.; Halabalaki, M.; Skaltsounis, L.A. Comparison Survey of EVOO Polyphenols and Exploration of Healthy Aging-Promoting Properties of Oleocanthal and Oleacein. Food Chem. Toxicol. 2019, 125, 403-412. [CrossRef]

191. Lerner, A.; Jeremias, P.; Matthias, T. The World Incidence and Prevalence of Autoimmune Diseases Is Increasing. Int. J. Celiac Dis. 2016, 3, 151-155. [CrossRef]

192. Rosillo, M.A.; Sánchez-Hidalgo, M.; Sánchez-Fidalgo, S.; Aparicio-Soto, M.; Villegas, I.; Alarcón-de-la-Lastra, C. Dietary Extra-Virgin Olive Oil Prevents Inflammatory Response and Cartilage Matrix Degradation in Murine Collagen-Induced Arthritis. Eur. J. Nutr. 2016, 55, 315-325. [CrossRef]

193. Smolen, J.S.; Aletaha, D.; McInnes, I.B. Rheumatoid Arthritis. Lancet 2016, 388, 2023-2038. [CrossRef]

194. Noble, P.W.; Bernatsky, S.; Clarke, A.E.; Isenberg, D.A.; Ramsey-Goldman, R.; Hansen, J.E. DNA-Damaging Autoantibodies and Cancer: The Lupus Butterfly Theory. Nat. Rev. Rheumatol. 2016, 12, 429-434. [CrossRef]

195. Aparicio-Soto, M.; Sánchez-Hidalgo, M.; Cárdeno, A.; González-Benjumea, A.; Fernández-Bolaños, J.G.; Alarcón-De-La-Lastra, C. Dietary Hydroxytyrosol and Hydroxytyrosyl Acetate Supplementation Prevent Pristane-Induced Systemic Lupus Erythematous in Mice. J. Funct. Foods 2017, 29, 84-92. [CrossRef]

196. Rees, F.; Doherty, M.; Grainge, M.J.; Lanyon, P.; Zhang, W. The Worldwide Incidence and Prevalence of Systemic Lupus erythematosus: A Systematic Review of Epidemiological Studies. Rheumatology (Oxford) 2017, 56, 1945-1961. [CrossRef] [PubMed]

197. De Oliveira, G.A.L.; De La Lastra, C.A.; Rosillo, M.Á.; Martinez, M.L.C.; Sánchez-Hidalgo, M.; Medeiros, J.V.R.; Villegas, I. Preventive Effect of Bergenin against the Development of TNBS-Induced Acute Colitis in Rats Is Associated with Inflammatory Mediators Inhibition and NLRP3/ASC Inflammasome Signaling Pathways. Chem. Interactions 2019, 297, 25-33. [CrossRef] [PubMed] 
198. Shivashankar, R.; Tremaine, W.J.; Harmsen, W.S.; Loftus, E.V. Incidence and Prevalence of Crohn's Disease and Ulcerative Colitis in Olmsted County, Minnesota from 1970 through 2010. Clin. Gastroenterol. Hepatol. 2017, 15, 857-863. [CrossRef]

199. Ilonen, J.; Lempainen, J.; Veijola, R. The Heterogeneous Pathogenesis of Type 1 Diabetes Mellitus. Nat. Rev. Endocrinol. 2019, 15, 635-650. [CrossRef]

200. Castejon, M.L.; Sánchez-Hidalgo, M.; Aparicio-Soto, M.; González-Benjumea, A.; Fernández-Bolaños, J.G.; Alarcón-De-La-Lastra, C. Olive Secoiridoid Oleuropein and Its Semisynthetic Acetyl-Derivatives Reduce LPS-Induced Inflammatory Response in Murine Peritoneal Macrophages via JAK-STAT and MAPKs Signaling Pathways. J. Funct. Foods 2019, 58, 95-104. [CrossRef]

201. Castejón, M.L.; Rosillo, M.Á.; Montoya, T.; González-Benjumea, A.; Fernández-Bolaños, J.G.; Alarcón-De-La-Lastra, C. Correction: Oleuropein Down-Regulated IL-1 $\beta$-Induced Inflammation and Oxidative Stress in Human Synovial Fibroblast Cell Line SW982. Food Funct. 2017, 8, 2341.

202. Ahmadvand, H.; Shahsavari, G.; Tavafi, M.; Bagheri, S.; Moradkhani, M.R.; Kkorramabadi, R.M.; Khosravi, P.; Jafari, M.; Zahabi, K.; Eftekhar, R.; et al. Protective Effects of Oleuropein against Renal Injury Oxidative Damage in Alloxan-Induced Diabetic Rats; a Histological and Biochemical study. J. Nephropathol. 2017, 6, 204-209. [CrossRef]

203. Zhang, J.-Y.; Yang, Z.; Fang, K.; Shi, Z.-L.; Ren, D.-H.; Sun, J. Oleuropein Prevents the Development of Experimental Autoimmune Myocarditis in Rats. Int. Immunopharmacol. 2017, 48, 187-195. [CrossRef]

204. Giner, E.; Recio, M.-C.; Ríos, J.-L.; Giner, R.-M. Oleuropein Protects Against Dextran Sodium Sulfate-Induced Chronic Colitis in Mice. J. Nat. Prod. 2013, 76, 1113-1120. [CrossRef]

205. Giner, E.; Andújar, I.; Recio, M.C.; Ríos, J.L.; Cerdá-Nicolás, J.M.; Giner, R.M. Oleuropein Ameliorates Acute Colitis in Mice. J. Agric. Food Chem. 2011, 59, 12882-12892. [CrossRef]

206. Impellizzeri, D.; Esposito, E.; Mazzon, E.; Paterniti, I.; Di Paola, R.; Morittu, V.M.; Procopio, A.; Britti, D.; Cuzzocrea, S. Oleuropein Aglycone, an Olive Oil Compound, Ameliorates Development of Arthritis Caused by Injection of Collagen Type II in Mice. J. Pharmacol. Exp. Ther. 2011, 339, 859-869. [CrossRef]

207. LaRussa, T.; Oliverio, M.; Suraci, E.; Greco, M.; Placida, R.; Gervasi, S.; Marasco, R.; Imeneo, M.; Paolino, D.; Tucci, L.; et al. Oleuropein Decreases Cyclooxygenase-2 and Interleukin-17 Expression and Attenuates Inflammatory Damage in Colonic Samples from Ulcerative Colitis Patients. Nutrients 2017, 9, 391. [CrossRef]

(C) 2020 by the authors. Licensee MDPI, Basel, Switzerland. This article is an open access article distributed under the terms and conditions of the Creative Commons Attribution (CC BY) license (http://creativecommons.org/licenses/by/4.0/). 